\title{
Efficient route to deuterated aromatics by the deamination of anilines
}

Kristyna Burglova ${ }^{\dagger}$, Sergei Okorochenkov ${ }^{\ddagger}$, Jan Hlavac ${ }^{\ddagger *}$

†Institute of Molecular and Translation Medicine, Faculty of Medicine, Palacký University,

Hněvotínská 5, 77900 Olomouc, Czech Republic

ॠDepartment of Organic Chemistry, Faculty of Science, Palacký University, 77146 Olomouc,

Czech Republic

\section{Supporting information}

\section{Table of content}

General experimental methods

General procedure for immobilization of a substrate to Rink resin through $-\mathrm{CO}_{2} \mathrm{H}$ function .................... 3

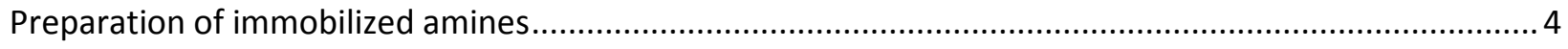

General procedure for deamination on solid phase - preparation of derivatives $2(\mathrm{R})$.......................... 14

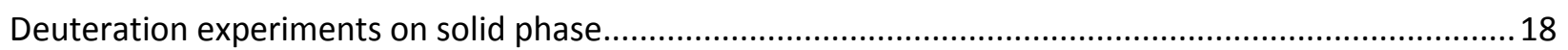

Immobilization of 1-methyl-2-aminoterephthalate on different resins and its deuteration ..................... 18

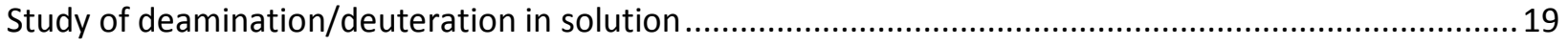

General procedure for deamination/deuteration in solution ............................................................ 19

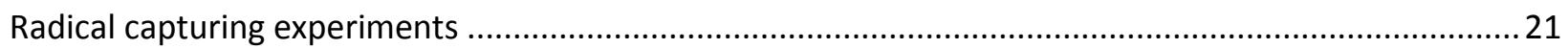

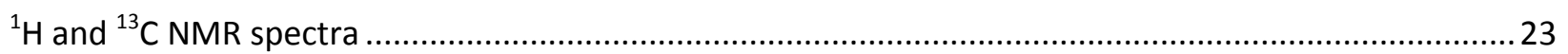

\section{General experimental methods}

LC/MS analyses were performed using UHPLC/MS with an UHPLC chromatograph Acquity with PDA detector and a single quadrupole mass spectrometer (Waters) with an X-Select C18 column at $30{ }^{\circ} \mathrm{C}$ and a flow rate of $600 \mu \mathrm{l} / \mathrm{min}$. The mobile phase consisted of (A) $0.01 \mathrm{M}$ 
ammonium acetate in water and (B) acetonitrile, with linearly programmed gradient over the course of $2.5 \mathrm{~min}$ and then maintains this concentration for $1.5 \mathrm{~min}$. The column was reequilibrated at $10 \% \mathrm{~B}$ for $1 \mathrm{~min}$. The APCI ionization operated at a discharge current of $5 \mu \mathrm{A}$, vaporizer temperature of $350{ }^{\circ} \mathrm{C}$ and capillary temperature of $200{ }^{\circ} \mathrm{C}$.

Purity of compounds was determined as ratio of appropriate peak area to sum of areas of all peaks of the mixture. Areas were determined by integration of the peaks from PDA detector response.

Purification was performed using semipreparative HPLC with a Waters 1500 series HPLC equipped with an Autosampler 2707, a Binary HPLC pump 1525, a Waters Photodiode Array Detector 2998 and a Waters Fraction Collector III with a YMC C18 reverse phase column, 20 x $100 \mathrm{~mm}$, with $5 \mu \mathrm{m}$ particles. The mobile phase consisted of acetonitrile and a $10 \mathrm{mM}$ aqueous ammonium acetate gradient over 6 min.

NMR spectra were measured in DMSO- $d_{6}$ using Jeol ECX-500 (500 MHz) spectrometer. Chemical shifts $(\delta)$ are reported in parts per million (ppm), and coupling constants $(J)$ are reported in Hertz (Hz). Acetate salts exhibited singlet at 1.7 - $1.9 \mathrm{ppm}$ in the ${ }^{1} \mathrm{H}$ NMR spectrum and two resonances at 173 and $23 \mathrm{ppm}$ in ${ }^{13} \mathrm{C}$ spectrum.

Solvents and chemicals were purchased from Sigma-Aldrich (Milwaukee, IL, www.sigmaaldrich.com) or Aapptec (USA,http://www.aapptec.com).

For the analysis of the product immobilized on the resin following procedure was used: analytical sample of resin ( $\sim 5 \mathrm{mg}$ ) was treated with $50 \% \mathrm{CF}_{3} \mathrm{COOH}$ in DCM for 30 min at room temperature, the cleavage cocktail was evaporated by a stream of nitrogen, and cleaved compound extracted into $1 \mathrm{~mL}$ of $\mathrm{MeOH}$ and analyzed on LC/MS.

Deprotection of $N$-Fmoc group was done as follows: resin (100 mg) was swelled in DMF (3x washing with $2 \mathrm{~mL}$ ) and was shaken in the solution of 50\% piperidine in DMF (2 mL) for 20 min. The resin was then washed with DMF (5x2 mL) and with DCM (3x2 mL) and used in next step. 


\section{General procedure for immobilization of a substrate to Rink resin through $-\mathrm{CO}_{2} \mathrm{H}$ function}

Fmoc protecting group of Rink resin (250 mg, $0.6 \mathrm{mmol} / \mathrm{g}, 100-200$ mesh) was deprotected. Subsequently, solution of carboxylic acid (1.5 mmol), DIC (234 $\mu \mathrm{L}, 1.5 \mathrm{mmol})$ and HOBt (230 mg, 1.5 mmol) in DMF (3 mL) was added. Slurry was stirred $2 \mathrm{~h}$ at room temperature. Then, resin was washed with DMF (5x4 mL) and DCM (3x4 mL) and used for next step.

This procedure was used for preparation of starting compounds $\mathbf{1}(\mathbf{1}), \mathbf{1 ( 1 3 ) ,} \mathbf{1 ( 1 4 )}$ and precursors $32-36$ used for the synthesis of other starting compounds $\mathbf{1 ( R )}$ (see later)

\section{1(1)}

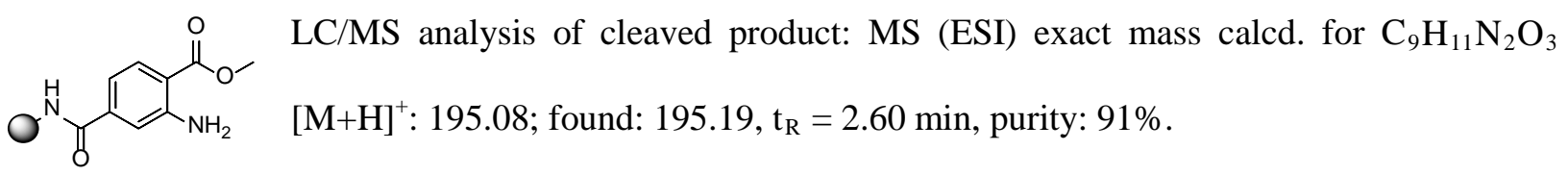

32<smiles>[NH2+]=CCCC(=O)NO</smiles>

LC/MS analysis of cleaved product: MS (ESI) exact mass calcd. for $\mathrm{C}_{19} \mathrm{H}_{21} \mathrm{~N}_{2} \mathrm{O}_{3}$ $[\mathrm{M}+\mathrm{H}]^{+}:$325.15; found: 325.16, $\mathrm{t}_{\mathrm{R}}=5.37 \mathrm{~min}$, purity: $99 \%$.

\section{3}

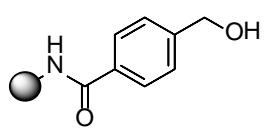

LC/MS analysis of cleaved product: MS (ESI) exact mass calcd. for $\mathrm{C}_{8} \mathrm{H}_{10} \mathrm{NO}_{2}$ $[\mathrm{M}+\mathrm{H}]^{+}$: 152.07; found: $152.07, \mathrm{t}_{\mathrm{R}}=0.77$ min, purity: $80 \%$.

\section{4}

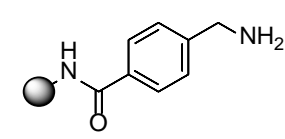

LC/MS analysis of cleaved product: MS (ESI) exact mass calcd. for $\mathrm{C}_{8} \mathrm{H}_{11} \mathrm{~N}_{2} \mathrm{O}$ $[\mathrm{M}+\mathrm{H}]^{+}:$151.17; found: $151.08, \mathrm{t}_{\mathrm{R}}=0.3 \mathrm{~min}$, purity: $99 \%$.

35

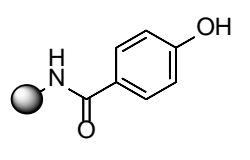

LC/MS analysis of cleaved product: MS (ESI) exact mass calcd. for $\mathrm{C}_{7} \mathrm{H}_{8} \mathrm{NO}_{2}[\mathrm{M}+\mathrm{H}]^{+}$: 138.05; found: $138.15, \mathrm{t}_{\mathrm{R}}=0.3 \mathrm{~min}$, purity: $99 \%$.

36 
$\mathrm{O}_{\mathrm{O}}^{\mathrm{N}} \mathrm{N}_{\mathrm{H}^{-}}^{\mathrm{Fh}}$

LC/MS analysis of cleaved product: MS (ESI) exact mass calcd. for $\mathrm{C}_{24} \mathrm{H}_{23} \mathrm{~N}_{2} \mathrm{O}_{3}$

$[\mathrm{M}+\mathrm{H}]^{+}$: 387.07; found: 387.17, $\mathrm{t}_{\mathrm{R}}=3.40 \mathrm{~min}$, purity: 99\%.

1(13)

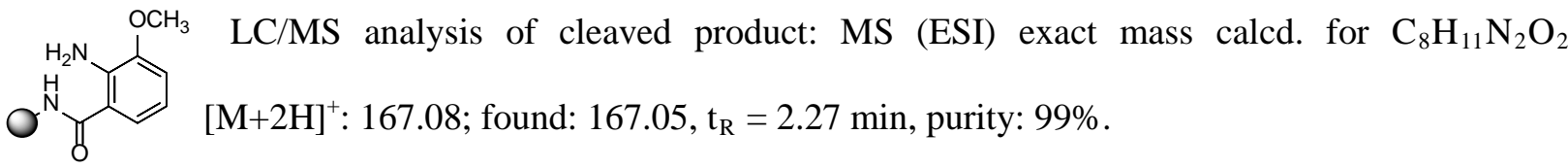

1(14)

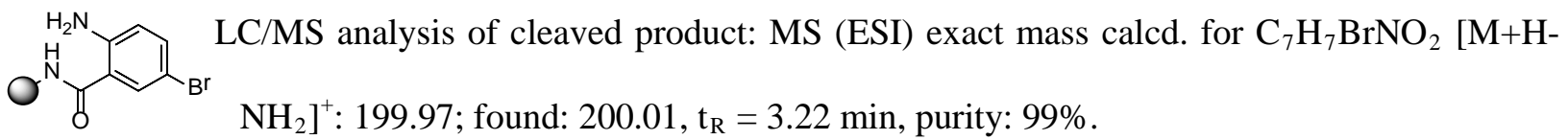

\section{Preparation of immobilized amines}

Amine 1(2) was prepared as follows: to the immobilized 4-(9H-fluoren-9ylmethoxycarbonylaminobutyric acid on the Rink resin 32 (100 mg, $0.6 \mathrm{mmol} / \mathrm{g}, 100-200 \mathrm{mesh}$ ) solution of 4-amino-3-bromobenzoic acid (324 mg, $1.5 \mathrm{mmol}$ ), DIC (234 $\mu \mathrm{L}, 1.5 \mathrm{mmol})$ and HOBt (244 mg, 1.5 mmol) in DMF (5 ml) was added and the slurry was shaken $2 \mathrm{~h}$ at room temperature. The resin was subsequently washed with DMF (3x10 mL), DCM (3x10 mL) and methanol (2x10 mL). LC/MS analysis of cleaved product: MS (ESI) exact mass calcd. for $\mathrm{C}_{11} \mathrm{H}_{15} \mathrm{BrN}_{3} \mathrm{O}_{2}[\mathrm{M}+\mathrm{H}]^{+}$: 300.03; found: 299.96, $\mathrm{t}_{\mathrm{R}}=$ 2.32 min, purity: 99\%.

Amine 1(3) was prepared according to the following scheme:

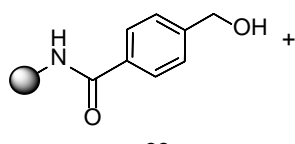

33
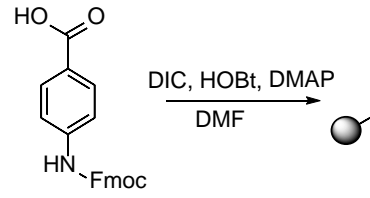

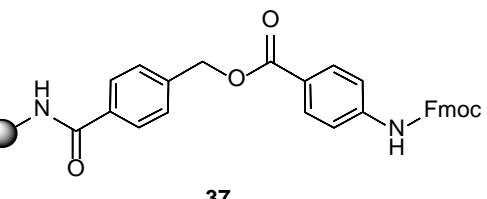

37

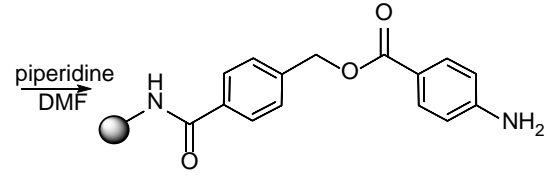

1(3)

Resin 33 (1000 mg) was washed with dichlorometane $(3 \times 10 \mathrm{~mL})$ and solution of 4-(9H-fluoren-9ylmethoxycarbonylamino)benzoic acid (538 mg, $1.5 \mathrm{mmol}$ ), DIC (234 uL, $1.5 \mathrm{mmol}$ ), DMAP (73 mg, $0.6 \mathrm{mmol}$ ) and HOBt (244 mg, $1.5 \mathrm{mmol})$ in DMF (1 mL) was added. Slurry was stirred for 2 
$\mathrm{h}$ at room temperature and washed with DMF $(3 \times 10 \mathrm{~mL}), \mathrm{DCM}(3 \times 2 \mathrm{~mL})$ and methanol $(2 \times 10$ $\mathrm{mL}$ ) to obtain resin 37. LC/MS analysis of cleaved product: MS (ESI) exact mass calcd. for $\mathrm{C}_{30} \mathrm{H}_{25} \mathrm{~N}_{2} \mathrm{O}_{5}[\mathrm{M}+\mathrm{H}]^{+}:$493.17; found: $493.60, \mathrm{t}_{\mathrm{R}}=7.80$ min, purity: $73 \%$.

The Fmoc group in derivative 37 was then removed to get amine 1(3). LC/MS analysis of cleaved product: MS (ESI) exact mass calcd. for $\mathrm{C}_{15} \mathrm{H}_{15} \mathrm{~N}_{2} \mathrm{O}_{3}[\mathrm{M}+\mathrm{H}]^{+}$: 271.11; found: 271.05, $\mathrm{t}_{\mathrm{R}}=3.82$ min, purity: $78 \%$.

The amine $\mathbf{1 ( 4 )}$ and $\mathbf{1 ( 5 )}$ were prepared according to the following scheme:
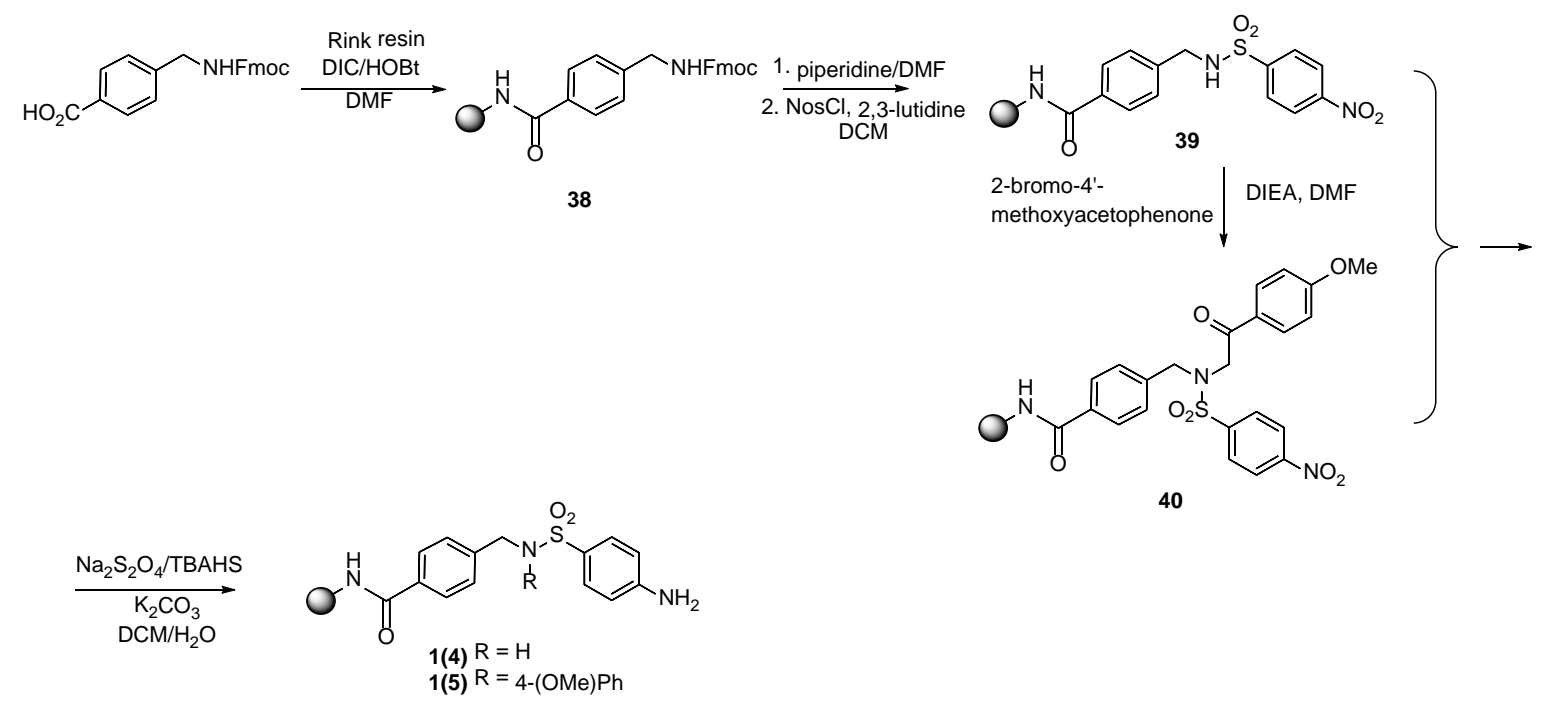

The resin 38 was prepared according to the General procedure for immobilization of a substrate to Rink resin through $-\mathrm{CO}_{2} \mathrm{H}$ function. MS (ESI) exact mass calcd. for $\mathrm{C}_{19} \mathrm{H}_{20} \mathrm{~N}_{7} \mathrm{O}_{3}[\mathrm{M}+\mathrm{H}]^{+}$: 373.15; found: 373.31, $\mathrm{t}_{\mathrm{R}}=2.80 \mathrm{~min}$, purity: 99\%. The Fmoc group was then deprotected and solution of NosCl (221 mg, $1.0 \mathrm{mmol}$ ) and 2,6-lutidine (116 uL, $1.0 \mathrm{mmol}$ ) in DCM (5 mL) was added. Slurry was stirred for $2 \mathrm{~h}$ at room temperature and washed with DMF $(3 \times 5 \mathrm{~mL})$ and DCM $(3 \times 5 \mathrm{~mL})$. LC/MS analysis of 39 after cleavage: MS (ESI) exact mass calcd. for $\mathrm{C}_{14} \mathrm{H}_{14} \mathrm{~N}_{3} \mathrm{O}_{5} \mathrm{~S}[\mathrm{M}+\mathrm{H}]^{+}$: 336.06; found: 336.16, $\mathrm{t}_{\mathrm{R}}=2.85$ min, purity: 99\%. One half of the resin 39 was alkylated by solution of 0.5 M 2-bromo-4'methoxyacetophenone (573 mg, $2.5 \mathrm{mmol}$ ) and 0.5 M DIEA (435 uL, $2.5 \mathrm{mmol}$ ) in $5 \mathrm{~mL}$ DMF for $16 \mathrm{~h}$ at room temperature to obtain resin 40. LC/MS analysis after cleavage: MS (ESI) exact mass calcd. for 
$\mathrm{C}_{23} \mathrm{H}_{22} \mathrm{~N}_{3} \mathrm{O}_{7} \mathrm{~S}[\mathrm{M}+\mathrm{H}]^{+}:$484.12; found: 484.23, $\mathrm{t}_{\mathrm{R}}=4.93$ min, purity: 99\%. The second half of the resin 39 and resin 40 (250 mg) were then reduced by addition of solution of $\mathrm{Na}_{2} \mathrm{~S}_{2} \mathrm{O}_{4}$ (204 mg, $1.0 \mathrm{mmol}$ ), $\mathrm{K}_{2} \mathrm{CO}_{3}$ (194 mg, $\left.1.4 \mathrm{mmol}\right)$ and TBAHS (51 mg, $\left.0.1 \mathrm{mmol}\right)$ in water (1.5 mL) and DCM (1.5 mL). The slurry was shaken at room temperature for $16 \mathrm{~h}$. The resin was washed three times with each solvent: DCM/water (1:1, v/v), DMF, MeOH and DCM.

1(4): LC/MS analysis after cleavage: MS (ESI) exact mass calcd. for $\mathrm{C}_{14} \mathrm{H}_{14} \mathrm{~N}_{3} \mathrm{O}_{3} \mathrm{~S}[\mathrm{M}-\mathrm{H}]^{-}$: 304.07; found: $304.23, \mathrm{t}_{\mathrm{R}}=4.17 \mathrm{~min}$, purity: $80 \%$.

1(5): LC/MS analysis after cleavage: MS (ESI) exact mass calcd. for $\mathrm{C}_{23} \mathrm{H}_{22} \mathrm{~N}_{3} \mathrm{O}_{5} \mathrm{~S}[\mathrm{M}-\mathrm{H}]$ : 452.13 ; found: $452.26, \mathrm{t}_{\mathrm{R}}=6.48 \mathrm{~min}$, purity: $85 \%$.

Amine 1(6) was prepared according to the following scheme:
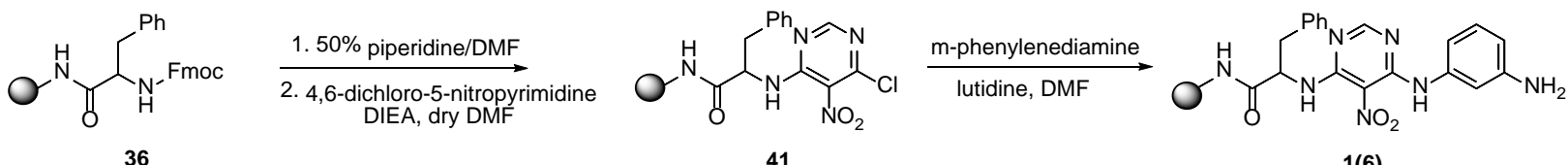

The resin 36 (300 mg) was deprotected and then shaken in the solution of 4,6-dichloro-5-nitropyrimidine (233 mg, $1.2 \mathrm{mmol})$ and DIEA (0.20 mL, $1.2 \mathrm{mmol})$ in dry DMF (4 mL) for $1.5 \mathrm{~h}$ at room temperature. The resin was then washed with DMF (3 x $4 \mathrm{~mL})$ and DCM $(3 \times 4 \mathrm{~mL})$ and used for next step. LC/MS analysis of 41 after cleavage: MS (ESI) exact mass calcd. for $\mathrm{C}_{13} \mathrm{H}_{13} \mathrm{ClN}_{5} \mathrm{O}_{3}[\mathrm{M}+\mathrm{H}]^{+}$: 322.07; found: 322.15, $\mathrm{t}_{\mathrm{R}}=2.64 \mathrm{~min}$, purity: 95\%. In the following step the resin $\mathbf{4 1}$ (300 $\mathrm{mg}$ ) was shaken in the solution of $\mathrm{m}$-phenylendiamine (216 $\mathrm{mg}, 2.0 \mathrm{mmol})$ and lutidine $(0.23 \mathrm{~mL}, 2.0 \mathrm{mmol})$ in DMF $(4 \mathrm{~mL})$ for $4 \mathrm{~h}$ at room temperature. The resin was then washed with DMF (3 x $4 \mathrm{~mL})$ and DCM (3 $x 4 \mathrm{~mL})$ and used for next step. LC/MS analysis of 1(6): MS (ESI) exact mass calcd. for $\mathrm{C}_{19} \mathrm{H}_{20} \mathrm{~N}_{7} \mathrm{O}_{3}[\mathrm{M}+\mathrm{H}]^{+}$: 394.16; found: 394.08, $\mathrm{t}_{\mathrm{R}}=2.01 \mathrm{~min}$, purity: $90 \%$. 
Amines 1(7) and $\mathbf{1 ( 9 )}$ were prepared according to the following scheme:

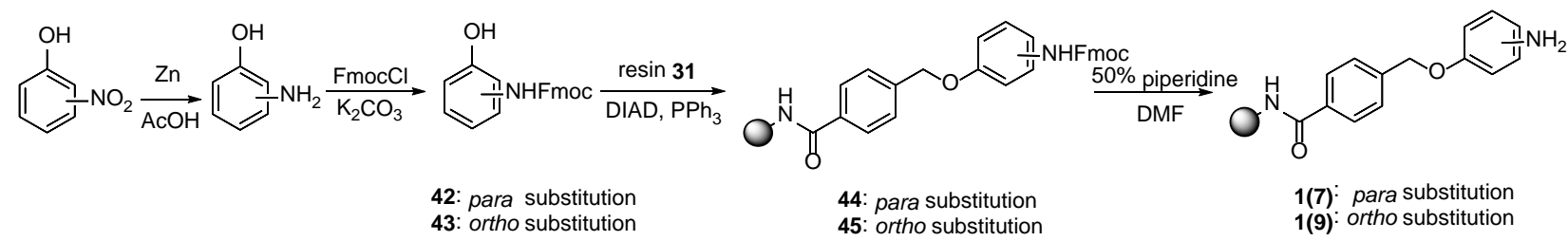

3- or 4-nitrophenol (500 mg, $4.6 \mathrm{mmol})$ and zinc dust (3 g) were mixed in acetic acid (2.60 mL) and THF (20 mL). The suspension was vigorously stirred for $1 \mathrm{~h}$ at $50{ }^{\circ} \mathrm{C}$. Then, it was cooled down to room temperature, filtered and the filtrate was evaporated to dryness under vacuum. It was then protected by Fmoc as follows: aminofenol was dissolved in THF $(5 \mathrm{~mL})$ and cooled to $0{ }^{0} \mathrm{C}$. Subsequently solution of $\mathrm{K}_{2} \mathrm{CO}_{3}$ (1270 mg, $9.2 \mathrm{mmol}$ ) in water (3 mL) was added in order to neutralize the residual acetic acid. Then, solution of Fmoc chloride (947 mg, $3.7 \mathrm{mmol}$ ) in THF (2 mL) was added dropwise. Mixture was stirred for $1 \mathrm{~h}$ at room temperature, concentrated under vacuum and the $\mathrm{pH}$ was adjusted to 4 by addition of 5\% HCl. Suspension was extracted with ethyl acetate $(10 \mathrm{~mL})$, organic layer was washed with water $(3 \times 10 \mathrm{~mL})$ and brine $(3 \times 10 \mathrm{~mL})$, dried over magnesium sulfate and evaporated under vacuum. The residue was purified on silica gel using DCM/acetonitrile (15:1 to 10:1) as the mobile phase.

LC/MS analysis of 42 after cleavage: MS (ESI) exact mass calcd. for $\mathrm{C}_{21} \mathrm{H}_{16} \mathrm{NO}_{3}$ [M-H]: 330.11; found: 330.10, $\mathrm{t}_{\mathrm{R}}=3.31 \mathrm{~min}$, purity: 99\%.

LC/MS analysis 43 after cleavage: MS (ESI) exact mass calcd. for $\mathrm{C}_{21} \mathrm{H}_{16} \mathrm{NO}_{3}[\mathrm{M}-\mathrm{H}]^{-}$: 330.11; found: $330.10, \mathrm{t}_{\mathrm{R}}=3.32 \mathrm{~min}$, purity: $99 \%$.

Mitsunobu condensation: Rink resin (20 mg, $0.6 \mathrm{mmol} / \mathrm{g}, 100-200 \mathrm{mesh}$ ) with deprotected amino group was swelled in dry THF (0.5 mL). The resin of 42 or $\mathbf{4 3}$ (33 mg, $0.2 \mathrm{mmol}$ ) was mixed with solution of $\mathrm{PPh}_{3}$ (52 mg, $0.2 \mathrm{mmol}$ ) in THF (0.5 mL). Suspension was cooled down to $-20^{\circ} \mathrm{C}$, shaken for $30 \mathrm{~min}$ followed by addition of DIAD (0.04 mL, $0.2 \mathrm{mmol})$ in dry THF (2 mL). Slurry was stirred for $3 \mathrm{~h}$ at room temperature. Then, resin was washed with $2 \times 2 \mathrm{~mL}$ THF, $5 \times 2 \mathrm{~mL}$ DMF and $3 \times 2 \mathrm{~mL}$ DCM. 
LC/MS analysis of $\mathbf{4 4}$ after cleavage: MS (ESI) exact mass calcd. for $\mathrm{C}_{29} \mathrm{H}_{23} \mathrm{~N}_{2} \mathrm{O}_{4}[\mathrm{M}-\mathrm{H}]$ : $: 463.17$; found: $463.09, \mathrm{t}_{\mathrm{R}}=3.38 \mathrm{~min}$, purity: $89 \%$.

LC/MS analysis of 45 after cleavage: MS (ESI) exact mass calcd. for $\mathrm{C}_{29} \mathrm{H}_{23} \mathrm{~N}_{2} \mathrm{O}_{4}[\mathrm{M}+\mathrm{H}]^{+}$: 465.17; found: $465.27, \mathrm{t}_{\mathrm{R}}=3.48 \mathrm{~min}$, purity: $93 \%$.

The Fmoc group was then deprotected by usual way to obtain amine $\mathbf{1 ( 7 )}$ or $\mathbf{1}(\mathbf{9})$ respectively.

Amine 1(8) was prepared according to the following scheme:

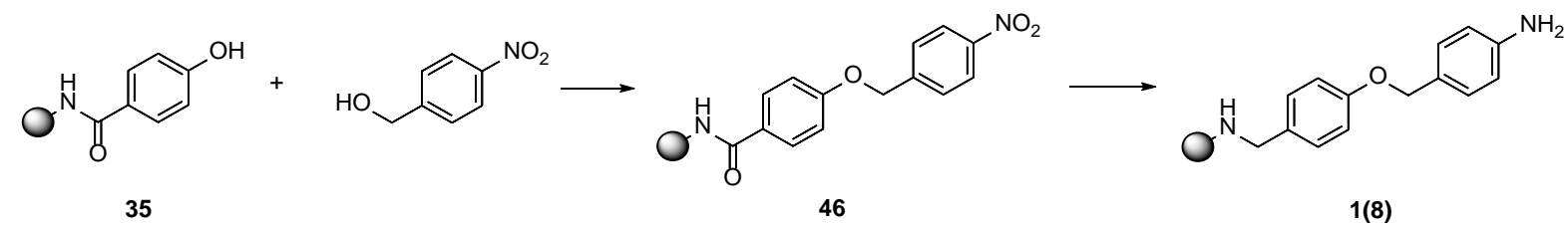

Resin 35 (100 mg) was shaken in solution of commercially available 4-nitrobenzylalcohol (31 mg, 0.2 mmol) and $\mathrm{PPh}_{3}(52 \mathrm{mg}, 0.2 \mathrm{mmol})$ in dry THF (1 mL). Suspension was cooled down to $-20{ }^{0} \mathrm{C}$ for 30 min and DIAD (39 uL, $0.2 \mathrm{mmol}$ ) was added in dry THF (0.2 mL). Slurry was stirred for 30 min at room temperature. The resin was then washed with THF (2x2 mL), DMF (5x2 mL) and DCM (3x2 mL). LC/MS analysis of $\mathbf{4 6}$ after cleavage: MS (ESI) exact mass calcd. for $\mathrm{C}_{14} \mathrm{H}_{13} \mathrm{~N}_{2} \mathrm{O}_{4}[\mathrm{M}-\mathrm{H}]:$ : 273.08; found: $273.18, \mathrm{t}_{\mathrm{R}}=2.37 \mathrm{~min}$, purity: $80 \%$.

Immobilized nitrocompound $\mathbf{4 6}$ was then reduced by shaking the resin (20 $\mathrm{mg})$ in the solution of viologen diiodide (10 mg, $0.02 \mathrm{mmol}$ ), potassium carbonate (74 mg, $0.7 \mathrm{mmol}$ ) and sodium dithionate (87 mg, 0.5 mmol) in 1:1 water/DCM mixture $(1 \mathrm{~mL})$ for $20 \mathrm{~h}$ at room temperature under inert atmosphere. Resin was washed with $2 \times 2 \mathrm{~mL}$ water, $5 \times 2 \mathrm{~mL}$ DMF and $3 \times 2 \mathrm{~mL}$ DCM. LC/MS analysis of 1(8): MS (ESI) exact mass calcd. for $\mathrm{C}_{14} \mathrm{H}_{14} \mathrm{~N}_{2} \mathrm{NaO}_{2}[\mathrm{M}+\mathrm{Na}]^{+}$: 265.09; found: 265.15, $\mathrm{t}_{\mathrm{R}}=1.59$ min, purity: 80\%.

Amine 1(10) was prepared according to the following scheme:

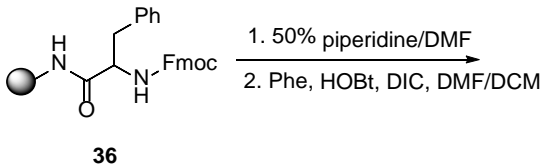

36

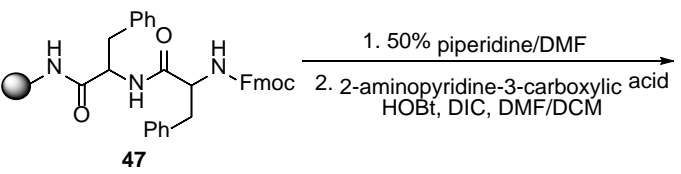

47

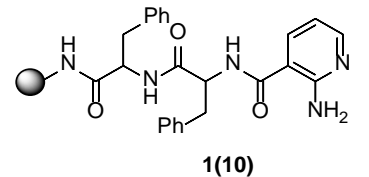

1(10) 
The resin 36 (300 mg) was deprotected and then shaken in the solution of phenylalanine (580 mg, 1.5 mmol), HOBt (202 mg, $1.5 \mathrm{mmol})$ and DIC (234 $\mu \mathrm{L} \mathrm{ml}, 1.5 \mathrm{mmol})$ in DMF (4 mL) for $1.5 \mathrm{~h}$ at room temperature. The resin was then washed with DMF (3 x $4 \mathrm{~mL})$ and DCM (3 x $4 \mathrm{~mL})$ and used for next step. LC/MS analysis of 47 after cleavage: MS (ESI) exact mass calcd. for $\mathrm{C}_{33} \mathrm{H}_{32} \mathrm{~N}_{3} \mathrm{O}_{4}[\mathrm{M}+\mathrm{H}]^{+}$: 534.24 ; found: 534.16, $t_{R}=3.45$, purity: $97 \%$. In the following step the resin 47 (300 mg) was shaken in the solution of 2-aminopyridine-3-carboxylic acid (207 mg, $1.5 \mathrm{mmol}$ ), HOBt (202 mg, $1.5 \mathrm{mmol}$ ) and DIC (234 $\mu \mathrm{L} \mathrm{ml}, 1.5 \mathrm{mmol}$ ) in DMF (4 mL) for $1.5 \mathrm{~h}$ at room temperature. The resin was then washed with DMF (3 x 4 mL) and DCM (3 x 4 mL) and used for next step. LC/MS analysis of 1(10) after cleavage: MS (ESI) exact mass calcd. for $\mathrm{C}_{24} \mathrm{H}_{26} \mathrm{~N}_{5} \mathrm{O}_{3}[\mathrm{M}+\mathrm{H}]^{+}$: 432.20; found: 2.23, $\mathrm{t}_{\mathrm{R}}=432.36$, purity: $90 \%$.

Amide 1(11) was prepared according to the following scheme:

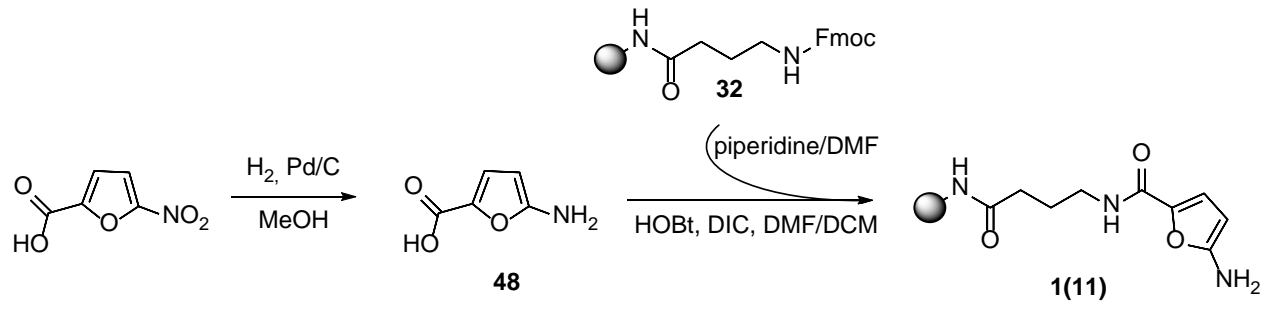

The amine 48 was prepared as follows: commercially available 5-nitrofuran-2-carboxylic acid (200 mg, $1.3 \mathrm{mmol})$ was dissolved in $\mathrm{MeOH}(10 \mathrm{~mL})$ and $10 \% \mathrm{Pd} / \mathrm{C}(20 \mathrm{mg})$ was added. The suspension was stirred for $2 \mathrm{~h}$ at room temperature with hydrogen bubbling through it. The suspension was filtered through celite and the solvent was evaporated under vacuum. LC/MS analysis of 48: MS (ESI) exact mass calcd. for $\mathrm{C}_{5} \mathrm{H}_{4} \mathrm{NO}_{3}[\mathrm{M}-\mathrm{H}]^{-}:$126.02; found: $126.05, \mathrm{t}_{\mathrm{R}}=0.53 \mathrm{~min}$, purity: 70\%. NMR spectra are in accordance with literature ${ }^{1}$. 1(11): The solution of amine 48 (38 mg, $\left.0.3 \mathrm{mmol}\right)$, DIC (0.05 mL, 0.3 mmol) and HOBt (47 mg, $0.3 \mathrm{mmol}$ ) in DMF (1 mL) was sucked into the syringe containing resin 32 (30 mg) where Fmoc groups had been deprotected. The mixture was stirred for $2 \mathrm{~h}$ at room temperature and washed with DMF (3x2 mL), DCM (3x2 mL) and MeOH (2x2 mL). LC/MS analysis of 1(11) after 
cleavage: MS (ESI) exact mass calcd. for $\mathrm{C}_{9} \mathrm{H}_{14} \mathrm{~N}_{3} \mathrm{O}_{3}[\mathrm{M}+\mathrm{H}]^{+}: 212.10$; found: $212.10, \mathrm{t}_{\mathrm{R}}=2.37$, purity: $82 \%$.

Amine 1(12) was prepared according to the following scheme:
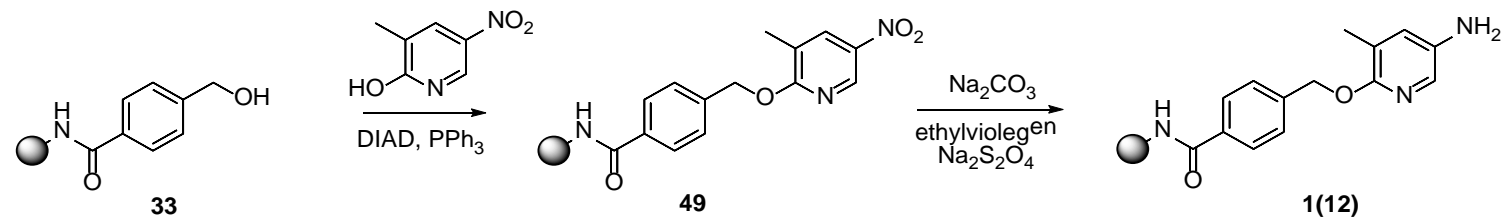

Resin 33 (20 mg) was swelled in dry THF (0.5 mL). Solution of 3-methyl-5-nitropyridin-2-ol (23 mg, 0.2 $\mathrm{mmol}$ ) and $\mathrm{PPh}_{3}$ (39 mg, $\left.0.2 \mathrm{mmol}\right)$ in THF $(0.5 \mathrm{~mL})$ was added to the syringe. Suspension was cooled down to $-20{ }^{\circ} \mathrm{C}$ for $30 \mathrm{~min}$ and DIAD $(0.03 \mathrm{~mL}, 0.2 \mathrm{mmol})$ in dry THF $(2 \mathrm{~mL})$ was added. Slurry was stirred for $3 \mathrm{~h}$ at room temperature. Then, resin 49 was washed with THF $(2 \times 2 \mathrm{~mL})$, DMF $(5 \times 2 \mathrm{~mL})$ and DCM $(3 \times 2 \mathrm{~mL})$. LC/MS analysis after cleavage: MS (ESI) exact mass calcd. for $\mathrm{C}_{14} \mathrm{H}_{12} \mathrm{~N}_{3} \mathrm{O}_{4}[\mathrm{M}-\mathrm{H}]$ : 286.08; found: $286.16, \mathrm{t}_{\mathrm{R}}=1.69$ min, purity: $85 \%$.

Resin 49 (20 mg) was swelled in DCM (1 mL) and ethyl viologen (10 mg) was added. Potassium carbonate (97 mg, $1.4 \mathrm{mmol}$ ) and sodium dithionite $(98 \mathrm{mg}, 1 \mathrm{mmol}$ ) were dissolved in $2 \mathrm{~mL}$ of DCM:water (1:1) in inert atmosphere and resulting emulsion was added to resin. Reaction mixture was stirred $16 \mathrm{~h}$ at room temperature. Then, resin was washed with water (2x1 mL), DMF (5x1 mL) and DCM (3x1 mL). LC/MS analysis after cleavage: MS (ESI) exact mass calcd. for $\mathrm{C}_{14} \mathrm{H}_{16} \mathrm{~N}_{3} \mathrm{O}_{2}[\mathrm{M}+\mathrm{H}]^{+}:$258.12; found: $258.09, \mathrm{t}_{\mathrm{R}}=2.30$, purity: $65 \%$. 
Amine 1(15) was prepared according to the following scheme:

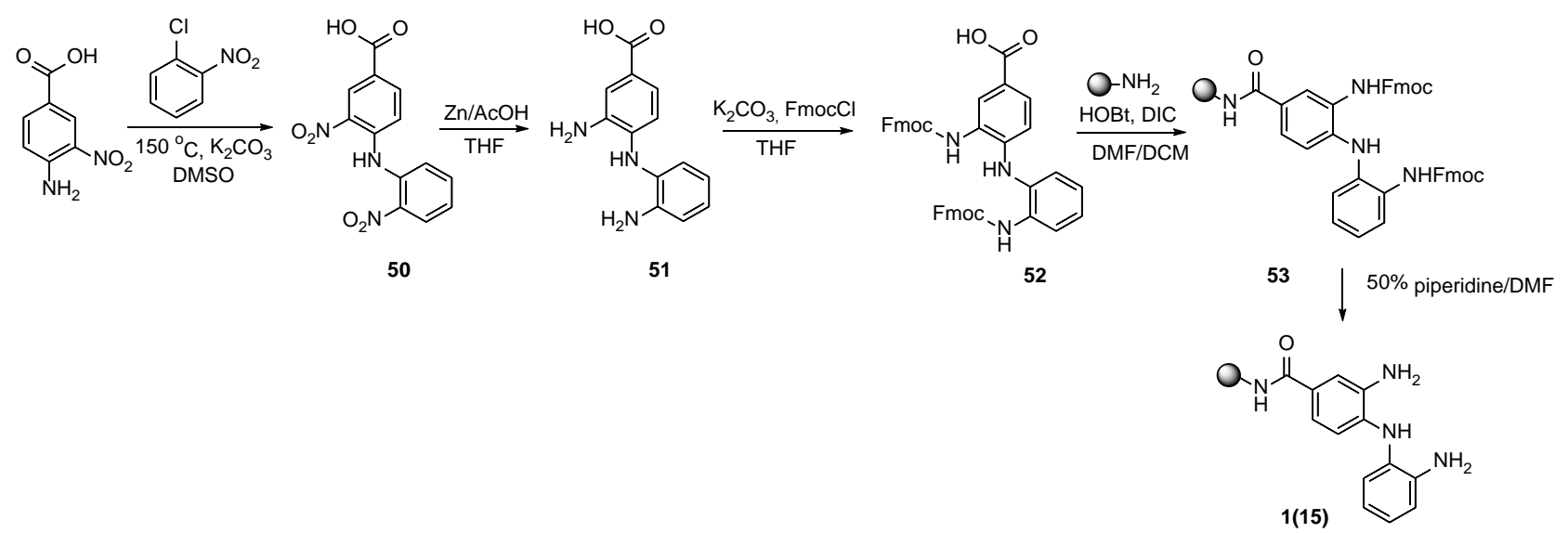

4-amino-2-nitrobenzoic acid (1440 mg, $7.9 \mathrm{mmol}$ ) and 1-chloro-2-nitrobenzene (500 mg, $3.2 \mathrm{mmol})$ were dissolved in DMSO (10 mL) and $\mathrm{K}_{2} \mathrm{CO}_{3}(3800 \mathrm{mg}, 17.4 \mathrm{mmol})$ was added. Resulting suspension was stirred under inert atmosphere for $12 \mathrm{~h}$ at $150{ }^{\circ} \mathrm{C} .5 \% \mathrm{HCl}$ in water $(100 \mathrm{~mL})$ was added; the solid residue was filtered off, washed with water and dried under vacuum. Residue was purified by column chromatography on silicagel with chloroform:formic acid (8:1) as the mobile phase to give derivative $\mathbf{5 0 .}$ LC/MS analysis: MS (ESI) exact mass calcd. for $\mathrm{C}_{13} \mathrm{H}_{8} \mathrm{~N}_{3} \mathrm{O}_{6}[\mathrm{M}-\mathrm{H}]^{-}: 302.04$; found: 302.10, $\mathrm{t}_{\mathrm{R}}=1.72$ min, purity: 95\%. ${ }^{1} \mathrm{H}$ NMR (500 MHz, $\mathrm{CDCl}_{3}$, ppm ) $\delta: 13.25$ (s, 1H), 10.79 (s, 1H), 8.65 (d, J = 2.0 Hz, $1 \mathrm{H}), 8.20\left(\mathrm{dd}, J_{1}=8.3 \mathrm{~Hz}, J_{2}=1.1 \mathrm{~Hz}, 1 \mathrm{H}\right), 8.06\left(\mathrm{dd}, J_{1}=8.8 \mathrm{~Hz}, J_{2}=2.0 \mathrm{~Hz}, 1 \mathrm{H}\right), 7.79-7.72(\mathrm{~m}, 2 \mathrm{H})$, $7.50(\mathrm{~d}, J=8.9 \mathrm{~Hz}, 1 \mathrm{H}), 7.39$ (ddd, $\left.J=8.5, J_{2}=6.6, J_{3}=2.0 \mathrm{~Hz}, 1 \mathrm{H}\right) .{ }^{13} \mathrm{C}$ NMR $\left(126 \mathrm{MHz}, \mathrm{DMSO}-d_{6}\right.$, ppm) $\delta: 165,142,141,136,135$ (2C), 134, 128, 126, 125, 124, 122, 118. Yield: $0.21 \mathrm{~g}(22 \%)$.

Compound 50 (140 mg, $0.5 \mathrm{mmol}$ ) was dissolved in THF (15 mL), zinc dust (300 mg) and acetic acid $(1.5 \mathrm{~mL})$ were added and suspension was vigorously stirred for $1 \mathrm{~h}$ at $50^{\circ} \mathrm{C}$. Then, suspension was cooled down to room temperature, filtered and the filtrate was evaporated under vacuum to give derivative $\mathbf{5 1 .}$ LC/MS analysis: MS (ESI) exact mass calcd. for $\mathrm{C}_{13} \mathrm{H}_{14} \mathrm{~N}_{3} \mathrm{O}_{2}[\mathrm{M}+\mathrm{H}]^{+}: 244.11$; found: 244.02, $\mathrm{t}_{\mathrm{R}}=2.78$, purity: $85 \%$.

The compound 51 (112 mg, $0.5 \mathrm{mmol}$ ) was dissolved in THF (5 mL) and cooled down to $0{ }^{\circ} \mathrm{C} . \mathrm{K}_{2} \mathrm{CO}_{3}$ (760 mg, $5.3 \mathrm{mmol})$ in water (3 mL) was added followed by dropwise addition of Fmoc-Cl (238 mg, 0.9 mmol) in THF (2 mL). Mixture was stirred $1 \mathrm{~h}$ at room temperature, concentrated under vacuum and the 
$\mathrm{pH}$ was adjusted to 4 by addition of $5 \% \mathrm{HCl}$. Suspension was extracted with ethyl acetate $(10 \mathrm{~mL})$, and organic layer was washed with water $(3 \times 10 \mathrm{~mL})$ and brine $(3 \times 10 \mathrm{~mL})$, dried over magnesium sulfate and evaporated under vacuum to give derivative 52. LC/MS analysis: MS (ESI) exact mass calcd. for $\mathrm{C}_{43} \mathrm{H}_{34} \mathrm{~N}_{3} \mathrm{O}_{6}[\mathrm{M}+\mathrm{H}]^{+}:$688.24; found: $688.28, \mathrm{t}_{\mathrm{R}}=4.04$, purity: $95 \%$.

Solution of 52 (200 mg, $0.3 \mathrm{mmol})$, DIC (0.05 mL, $0.3 \mathrm{mmol}$ ), and HOBt (47 mg, $0.3 \mathrm{mmol})$ in DMF (2 mL) was mixed with Fmoc-deprotected Rink resin (300 mg, 0.6 mmol/g, 100-200 mesh). Slurry was stirred for $8 \mathrm{~h}$ at room temperature and washed with DMF $(3 \times 5 \mathrm{~mL})$, DCM $(3 \times 5 \mathrm{~mL})$ and methanol $(2 \times 5$ $\mathrm{mL}$ ) to give resin 53. LC/MS analysis: MS (ESI) exact mass calcd. for $\mathrm{C}_{43} \mathrm{H}_{35} \mathrm{~N}_{4} \mathrm{O}_{5}[\mathrm{M}+\mathrm{H}]^{+}$: 687.26; found: $687.30, t_{R}=3.80$, purity: $80 \%$. The Fmoc groups were deprotected and obtained resin 1(15) was used directly in the next step. LC/MS analysis after cleavage: MS (ESI) exact mass calcd. for $\mathrm{C}_{13} \mathrm{H}_{15} \mathrm{~N}_{4} \mathrm{O}$ $[\mathrm{M}+\mathrm{H}]^{+}:$243.13; found: $243.30, \mathrm{t}_{\mathrm{R}}=2.80$, purity: $80 \%$.

Amines 1(16) and $\mathbf{1 ( 1 8 )}$ were prepared under the procedure for the amines $\mathbf{1}(\mathbf{2})$ and $\mathbf{1 ( 4 )}$ respectively. The Wang resin (0.85 mmol/g, 100-200 mesh) was used instead of Rink resin.

\section{1(16)}

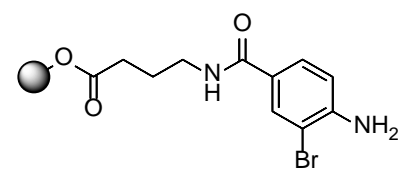

LC/MS analysis (analyzed as methylester formed during the cleavage): MS

(ESI) exact mass calcd. for $\mathrm{C}_{12} \mathrm{H}_{15} \mathrm{~N}_{2} \mathrm{O}_{3} \mathrm{Br}[\mathrm{M}-\mathrm{H}]^{-}$: 314.03; found: 314.95, $\mathrm{t}_{\mathrm{R}}$

$=2.49$, purity: $95 \%$.

1(18)

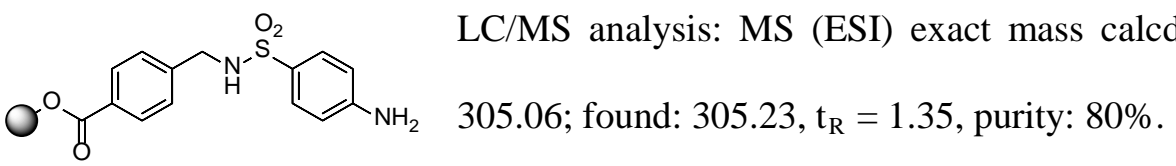

Amine 1(17) was prepared according to the following scheme:

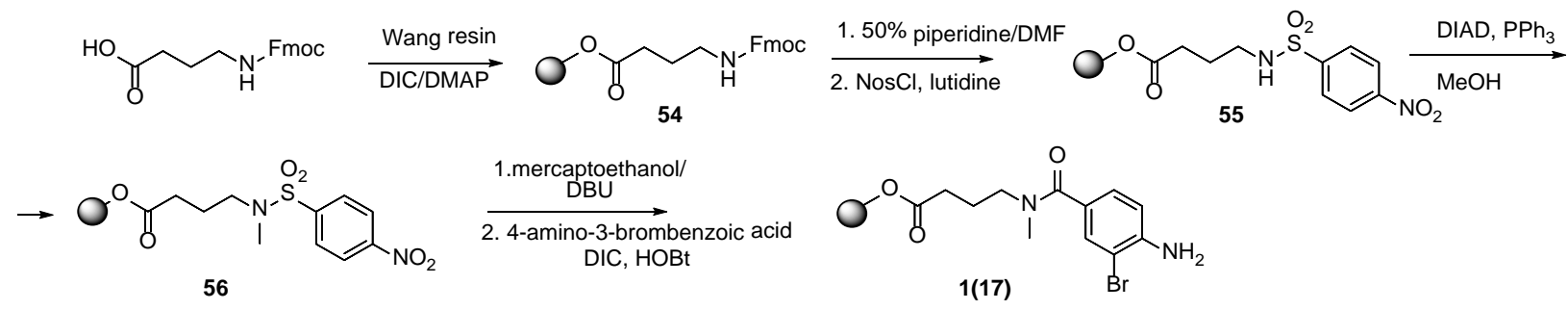


The resin $\mathbf{5 4}$ was prepared according to the General procedure was immobilization of substrate through $\mathrm{CO}_{2} \mathrm{H}$ function and was used directly in next step. $500 \mathrm{mg}$ of the resin $\mathbf{5 4}$ was stirred with solution of $\operatorname{NosCl}$ (330 mg, $1.5 \mathrm{mmol})$ and 2,6-lutidine (0.2 mL, $1.5 \mathrm{mmol}$ ) in DCM (3 mL) for $2 \mathrm{~h}$ at room temperature to afford resin 55 . The resin was washed with DMF $(3 \times 5 \mathrm{~mL})$ and DCM $(3 \times 5 \mathrm{~mL})$. LC/MS analysis after cleavage (analyzed as methylester): MS (ESI) exact mass calcd. for $\mathrm{C}_{10} \mathrm{H}_{13} \mathrm{~N}_{2} \mathrm{O}_{6} \mathrm{~S}[\mathrm{M}+\mathrm{H}]^{+}$: 289.05; found: 289.15, $\mathrm{t}_{\mathrm{R}}=1.38$, purity: 99\%. Subsequently, the resin 55 (500 mg) was stirred with solution of methanol $(0.06 \mathrm{uL}, 1.5 \mathrm{mmol})$ and $\mathrm{PPh}_{3}(393 \mathrm{mg}, 1.5 \mathrm{mmol})$ in dry THF $(3 \mathrm{~mL})$ at $-20^{\circ} \mathrm{C}$ for $30 \mathrm{~min}$. Then DIAD $(0.3 \mathrm{uL}, 1.5 \mathrm{mmol})$ in dry THF $(0.5 \mathrm{~mL})$ was added and it was stirred for $3 \mathrm{~h}$ at room temperature to give resine 56 . The resin was washed with $2 \times 5 \mathrm{~mL}$ THF, $5 \times 5 \mathrm{~mL} \mathrm{DMF}$ and $3 \times 5 \mathrm{~mL}$ DCM. LC/MS analysis after cleavage (analyzed as methylester): MS (ESI) exact mass calcd. for $\mathrm{C}_{11} \mathrm{H}_{15} \mathrm{~N}_{2} \mathrm{O}_{6} \mathrm{~S}[\mathrm{M}+\mathrm{H}]^{+}:$303.06; found: $303.15, \mathrm{t}_{\mathrm{R}}=1.38$, purity: 99\%. Nosyl group was then deprotected by stirring the resin 56 (500 mg) in solution of mercaptoethanol $(210 \mu \mathrm{L}, 3 \mathrm{mmol})$ and DBU $(149 \mu \mathrm{L}, 1$ mmol) in DMF (5 mL) for 30 min at room temperature. After the washing with DMF (3x5 mL) and DCM (3x5 mL), the resin was stirred with solution of 4-amino-3-bromobenzoic acid (324 mg, $1.5 \mathrm{mmol}$ ), DIC (0.2 mL, $1.5 \mathrm{mmol}$ ), and HOBt (244 mg, $1.5 \mathrm{mmol}$ ) in DMF (5 mL) for $2 \mathrm{~h}$ at room temperature finished by washing with DMF $(3 \times 10 \mathrm{~mL})$, DCM $(3 \times 10 \mathrm{~mL})$ and methanol $(2 \times 10 \mathrm{~mL})$ to obtain amine $\mathbf{1}(\mathbf{1 7})$. LC/MS analysis after cleavage: MS (ESI) exact mass calcd. for $\mathrm{C}_{12} \mathrm{H}_{14} \mathrm{~N}_{2} \mathrm{O}_{3} \mathrm{Br}[\mathrm{M}-\mathrm{H}]$ : : 313.02; found: $313.95, \mathrm{t}_{\mathrm{R}}=4.20$, purity: $90 \%$.

Amine 1(19) was prepared according to the following scheme:

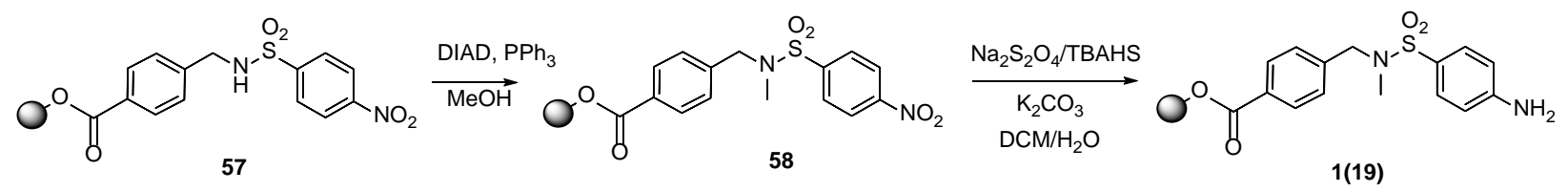


The alkylation of $\mathbf{5 7}$ and following reduction of $\mathbf{5 8}$ were done in the same way as preparation of compounds 56 and 1(17) respectively. 1(19): LC/MS analysis: MS (ESI) exact mass calcd. for $\mathrm{C}_{15} \mathrm{H}_{15} \mathrm{~N}_{2} \mathrm{O}_{4} \mathrm{~S}$ [M-H] $:$ 319.06; found: 319.07, $\mathrm{t}_{\mathrm{R}}=2.85$, purity: $80 \%$.

\section{1(20)}

follows: solution of the acid (560 mg, $3.0 \mathrm{mmol})$, DIC (0.5 ml, $3.0 \mathrm{mmol})$ and DMAP (61 mg, $0.5 \mathrm{mmol})$ in DMF (10 mL) was added to low-loading Wang resin (500 mg) previously swelled in DCM. Slurry was stirred for $2 \mathrm{~h}$ at room temperature and washed with DMF $(3 \times 5 \mathrm{~mL})$, DCM $(3 \times 5$ $\mathrm{mL})$ and methanol $(2 \times 5 \mathrm{~mL})$. LC/MS analysis after cleavage: MS (ESI) exact mass calcd. for $\mathrm{C}_{8} \mathrm{H}_{8} \mathrm{NO}_{3}$ $[\mathrm{M}-\mathrm{H}]^{-}:$166.05; found: $166.10, \mathrm{t}_{\mathrm{R}}=2.17$, purity: $99 \%$.

\section{General procedure for deamination on solid phase - preparation of derivatives 2(R)}

Resin (300 mg) bearing immobilized amine was treated with mixture of $\mathrm{NaNO}_{2}$ (140 mg, $2.0 \mathrm{mmol}$ ), AcOH (0.4 ml), DCM (2 mL) and water (2 mL). The resulting mixture was stirred vigorously for $30 \mathrm{~min}$ at room temperature. Finally, the resin was washed with mixture of DCM and water ( $3 x 4 \mathrm{~mL}), \mathrm{DMF}(3 \mathrm{x} 4$ $\mathrm{mL})$ and DCM (3x4 mL). The deaminated product was cleaved from the resin and purified by HPLC.

\section{2(1)}

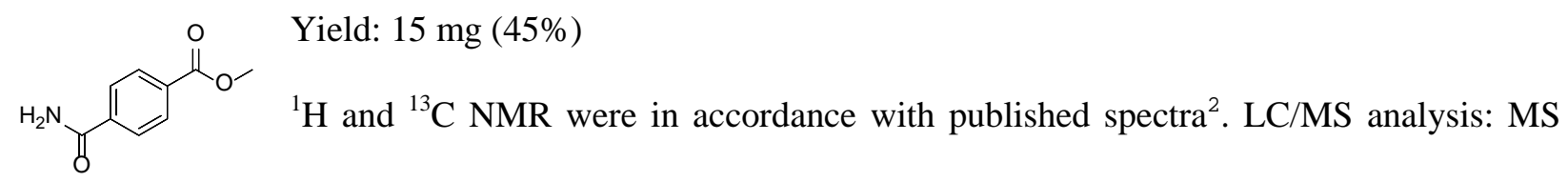
(ESI) exact mass calcd. for $\mathrm{C}_{9} \mathrm{H}_{10} \mathrm{NO}_{3}[\mathrm{M}+\mathrm{H}]^{+}:$180.06; found: $180.25, \mathrm{t}_{\mathrm{R}}=0.81 \mathrm{~min}$, purity: 99\%.

2(2)

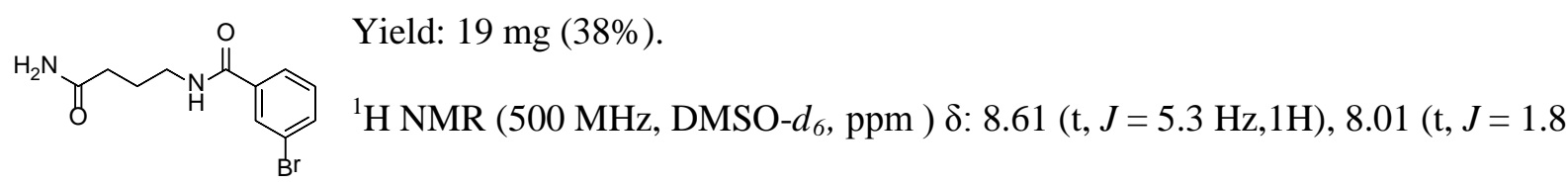


$\mathrm{Hz}, 1 \mathrm{H}$ ), $7.84\left(\mathrm{dt}, J_{1}=10 \mathrm{~Hz}, J_{2}=1.5 \mathrm{~Hz} 1 \mathrm{H}\right), 7.72\left(\mathrm{ddd}, J_{1}=8.0 \mathrm{~Hz}, J_{2}=2.0 \mathrm{~Hz}, J_{3}=1.0 \mathrm{~Hz}, 1 \mathrm{H}\right), 7.43$ (t, $J=7.9 \mathrm{~Hz}, 1 \mathrm{H}), 7.29$ (s, 1H), $6.75(\mathrm{~s}, 1 \mathrm{H}), 3.25$ (dd, $\left.J_{1}=12.7 \mathrm{~Hz}, J_{2}=6.9 \mathrm{~Hz}, 2 \mathrm{H}\right), 2.11(\mathrm{t}, J=7.5 \mathrm{~Hz}$, 2H), 1.73 (p, $J=7.3 \mathrm{~Hz} 2 \mathrm{H}) .{ }^{13} \mathrm{C}$ NMR (126 MHz, DMSO-d 6 , ppm) $\delta: 174,165,137,134,131,130,126$, 121, 39, 33, 25. HRMS (ESI+) m/z: $[\mathrm{M}+1]^{+}$calcd for $\mathrm{C}_{11} \mathrm{H}_{14} \mathrm{BrN}_{2} \mathrm{O}_{2}$ 285.0233; found: 285.0234, $\mathrm{t}_{\mathrm{R}}=$ 3.28 min, purity: 99\%.

2(3)

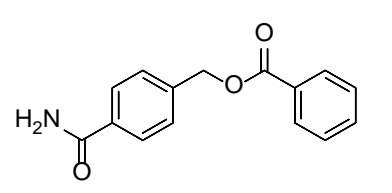

Yield: 18 mg (39\%).

${ }^{1} \mathrm{H}$ NMR (500 MHz, $\left.\mathrm{CDCl}_{3}, \mathrm{ppm}\right) \delta: 8.08\left(\mathrm{dd}, J_{1}=8.3 \mathrm{~Hz}, J_{2}=1.3 \mathrm{~Hz}, 2 \mathrm{H}\right)$, $7.84(\mathrm{~d}, J=8.3 \mathrm{~Hz}, 2 \mathrm{H}), 7.58\left(\mathrm{tt}, J_{1}=2.0 \mathrm{~Hz}, J_{2}=9.5 \mathrm{~Hz} 1 \mathrm{H}\right), 7.53(\mathrm{~d}, J=8.3$

Hz, 2H), 7.46 (t, $J=7.7 \mathrm{~Hz}, 2 \mathrm{H}), 5.42$ (s, 2H). ${ }^{13} \mathrm{C}$ NMR (126 MHz, DMSO-d 6 , ppm) $\delta: 168,166,139$, 134 (2C), 129 (2C), 128, 127, 66. HRMS (ESI+) m/z: [M+1] $]^{+}$calcd for $\mathrm{C}_{15} \mathrm{H}_{14} \mathrm{NO}_{3}$ 256.0968; found: 256.0968, $\mathrm{t}_{\mathrm{R}}=4.98 \mathrm{~min}$, purity: $99 \%$.

2(4)

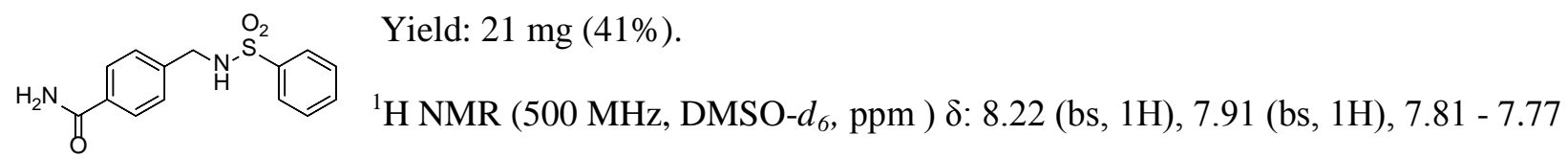
(m, 4H), 7.64 (t, $J=7.3 \mathrm{~Hz}, 1 \mathrm{H}), 7.58$ (t, $J=7.4 \mathrm{~Hz}, 2 \mathrm{H}), 7.32$ (bs, 2H),7.29 (d, $J=8 \mathrm{~Hz}, 1 \mathrm{H}), 4.04$ (d, $J$ $=5.1 \mathrm{~Hz}, 2 \mathrm{H}) .{ }^{13} \mathrm{C}$ NMR (126 MHz, DMSO- $\left.{ }_{6}, \mathrm{ppm}\right) \delta: 168,141$ (2C), 133, 132, 129, 127 (2C), 126, 46. HRMS (ESI+) m/z: [M+1] ${ }^{+}$calcd for $\mathrm{C}_{14} \mathrm{H}_{15} \mathrm{~N}_{2} \mathrm{O}_{3} \mathrm{~S}$ 291.0798; found: 291.0799, $\mathrm{t}_{\mathrm{R}}=4.17$ min, purity: $99 \%$.

2(5)

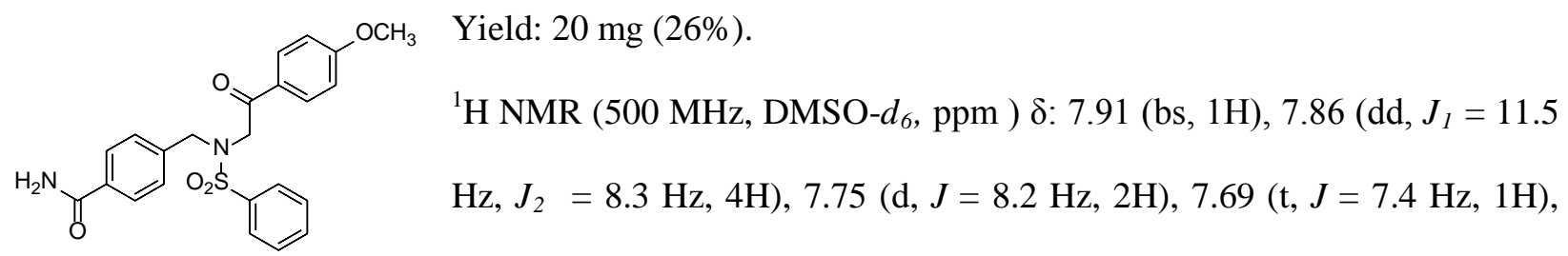


7.59 (t, $J=7.7 \mathrm{~Hz}, 2 \mathrm{H}), 7.33$ (bs, 1H), 7.24 (d, $J=8.2 \mathrm{~Hz}, 2 \mathrm{H}), 6.99$ (d, $J=8.9 \mathrm{~Hz}, 2 \mathrm{H}), 4.73$ (s, 2H), 4.49 (s, 2H), $3.82(\mathrm{~s}, 3 \mathrm{H})$.

${ }^{13} \mathrm{C}$ NMR (126 MHz, DMSO-d $d_{6}$ ppm) $\delta: 192,167,163,140,139,133$ (2C), 130, 129, 128, 127 (2C), 114, 56, 53, 51. HRMS (ESI+) m/z: $[\mathrm{M}+1]^{+}$calcd for $\mathrm{C}_{23} \mathrm{H}_{23} \mathrm{~N}_{2} \mathrm{O}_{5} \mathrm{~S}$ 439.1322; found: 439.1323, $\mathrm{t}_{\mathrm{R}}=$ 6.48 min, purity: 99\%.

\section{2(6)}

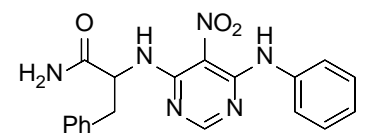

Yield: $29 \mathrm{mg}$ (43\%).

${ }^{1} \mathrm{H}$ NMR (400 MHz, DMSO- $\left.d_{6}, \mathrm{ppm}\right) \delta: 9.49$ (d, $\left.J=6 \mathrm{~Hz}, 1 \mathrm{H}\right), 8.12$ (s, $\left.1 \mathrm{H}\right)$, $7.58(\mathrm{~d}, J=8 \mathrm{~Hz}, 2 \mathrm{H}), 7.38$ (t, $J=8 \mathrm{~Hz}, 2 \mathrm{H}), 7.27-7.18(\mathrm{~m}, 8 \mathrm{H}), 4.93$ (q, J = $6 \mathrm{~Hz}, 1 \mathrm{H}), 3-31-3.20(\mathrm{~m}$, 2H). ${ }^{13} \mathrm{C}$ NMR (126 MHz, DMSO-d ${ }_{6}$, ppm) $\delta: 171.8,159.3,155.8,155.4,137.3,137.0,129.4,128.6$, 128.2, 126.6, 125.5, 124.5, 112.5, 55.8, 36.7. HRMS (ESI+) m/z: $[M+1]^{+}$calcd for $\mathrm{C}_{19} \mathrm{H}_{19} \mathrm{~N}_{6} \mathrm{O}_{3}$ 379.1513; found: $379.1514, \mathrm{t}_{\mathrm{R}}=2.33 \mathrm{~min}$, purity: $99 \%$.

\section{2(7)}

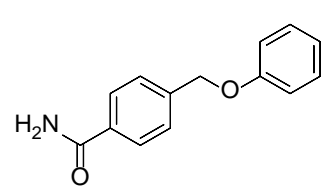

Yield: $12 \mathrm{mg}(30 \%)$.

${ }^{1} \mathrm{H}$ NMR (400 MHz, DMSO-d ${ }_{6}$, ppm) $\delta: 7.97$ (br, 1H), 7.88 (d, $\left.J=6.6 \mathrm{~Hz}, 2 \mathrm{H}\right), 7.51$ (d, $J=8.3 \mathrm{~Hz}, 2 \mathrm{H}), 7.37$ (br, 1H), 7.29 (dd, $\left.J_{1}=8.7 \mathrm{~Hz}, J_{2}=7.3 \mathrm{~Hz}, 2 \mathrm{H}\right), 7.01$ (dd, $\left.J_{1}=8.8 \mathrm{~Hz}, J_{2}=1.0 \mathrm{~Hz}, 2 \mathrm{H}\right), 6.94\left(\mathrm{tt}, J_{1}=7.6 \mathrm{~Hz}, J_{2}=1.0 \mathrm{~Hz}, 1 \mathrm{H}\right), 5.16(\mathrm{~s}, 2 \mathrm{H}) .{ }^{13} \mathrm{C} \mathrm{NMR}(126 \mathrm{MHz}$, DMSO- $d_{6}$, ppm) $\delta: 168,158,140,134,130,128,127,121,115,69$. HRMS (ESI+) m/z: [M+1] $]^{+}$calcd for $\mathrm{C}_{14} \mathrm{H}_{14} \mathrm{NO}_{2}$ 228.1019; found: 228.1020, $\mathrm{t}_{\mathrm{R}}=2.35$ min, purity: 99\%.

\section{2(8)}

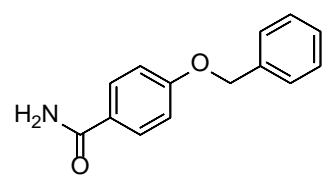

Yield: $13 \mathrm{mg}(32 \%)$.

${ }^{1} \mathrm{H}$ NMR (400 MHz, DMSO-d 6 , ppm) $\delta: 7.87$ - 7.80 (m, 3H), 7.46 - 7.32 (m, 5H), 7.16 (br, 1H), 7.05 (d, $J=8.8 \mathrm{~Hz}, 2 \mathrm{H}), 5.16$ (s, 2H). ${ }^{13} \mathrm{C}$ NMR (126 MHz, DMSO- 
$\left.d_{6}, \mathrm{ppm}\right) \delta: 167,161,137,129,128(3 \mathrm{C}), 127,114,69$. HRMS (ESI+) m/z: $[\mathrm{M}+1]^{+}$calcd for $\mathrm{C}_{14} \mathrm{H}_{14} \mathrm{NO}_{2}$ 228.1019; found: $228.1020, \mathrm{t}_{\mathrm{R}}=2.33 \mathrm{~min}$, purity: $98 \%$.

2(9)

Yield: $8 \mathrm{mg}(19 \%)$.

4(13)

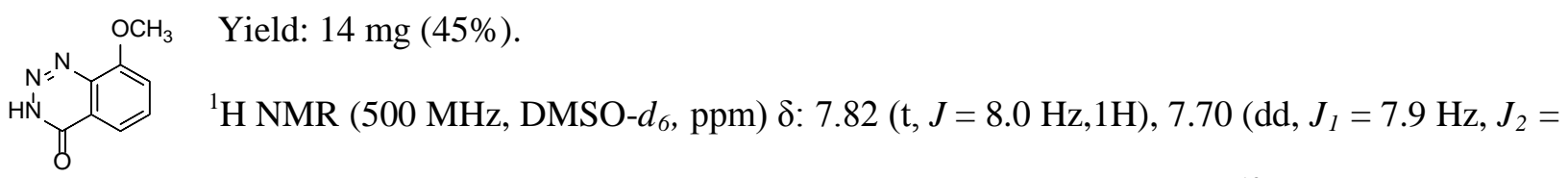
$1.1 \mathrm{~Hz}, 1 \mathrm{H}), 7.60$ (dd, $\left.J_{1}=8.2 \mathrm{~Hz}, J_{2}=1.1 \mathrm{~Hz}, 1 \mathrm{H}\right), 4.01$ (s, 3H). ${ }^{13} \mathrm{C}$ NMR $(126 \mathrm{MHz}$, DMSO- $_{6}$, ppm) $\delta: 156,155,135,134,121,116,115,56$. HRMS (ESI+) m/z: [M-1] calcd for $\mathrm{C}_{8} \mathrm{H}_{6} \mathrm{~N}_{3} \mathrm{O}_{2}$ 176.0466; found: $176.0450, \mathrm{t}_{\mathrm{R}}=2.17$ min, purity: 99\%.

4(14)

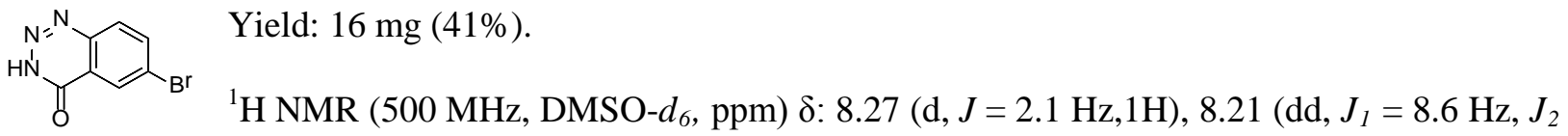
$=2.2 \mathrm{~Hz} 1 \mathrm{H}), 8.09$ (d, $J=8.6 \mathrm{~Hz}) .{ }^{13} \mathrm{C}$ NMR (126 MHz, DMSO-d 6 , ppm) $\delta: 154,143,138,130,127$, 156, 122. HRMS (ESI+) m/z: [M-1] calcd for $\mathrm{C}_{7} \mathrm{H}_{3} \mathrm{BrN}_{3} \mathrm{O}$ 223.9465; found: 223.9453, purity: 99\%.

$5(15)$

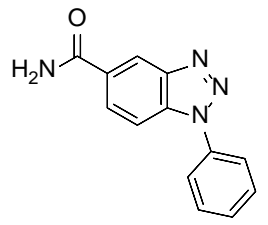

Yield: 9 mg (22\%).

${ }^{1} \mathrm{H}_{\mathrm{NMR}}\left(500 \mathrm{MHz}, \mathrm{DMSO}-\mathrm{d}_{6}\right.$, ppm) $\delta: 8.74$ (s, 1H), 8.23 (br, $\left.1 \mathrm{H}\right), 8.17$ (dd, $J_{1}=8.8$

$\left.\mathrm{Hz}, J_{2}=1.2 \mathrm{~Hz}, 1 \mathrm{H}\right), 7.98\left(\mathrm{dd}, J_{1}=8.7 \mathrm{~Hz}, J_{2}=0.7 \mathrm{~Hz}, 1 \mathrm{H}\right), 7.91(\mathrm{~d}, J=7.3 \mathrm{~Hz}$,

2H), 7.72 (t, $J=7.6 \mathrm{~Hz}, 2 \mathrm{H}), 7.62$ (t, $J=6.9 \mathrm{~Hz}, 1 \mathrm{H}), 7.55$ (br, $1 \mathrm{H}) .{ }^{13} \mathrm{C}$ NMR (126 MHz, DMSO- $d_{6}$, ppm) $\delta: 167,146,136,133,131,130,129,128,123,119,111$. HRMS (ESI+) m/z: [M+1] ${ }^{+}$calcd for $\mathrm{C}_{13} \mathrm{H}_{11} \mathrm{~N}_{4} \mathrm{O}$ 239.0927; found: 239.0929, $\mathrm{t}_{\mathrm{R}}=1.94$ min, purity: 99\%. 


\section{Deuteration experiments on solid phase}

Resins with immobilized amines were dried and washed with $\mathrm{CDCl}_{3}$. The deuteration experiments were done according to the same protocol as deamination but using $\mathrm{CDCl}_{3}$ instead of $\mathrm{CHCl}_{3}$. The results are summarized in Table 1.

Table 1: Deuteration experiments on solid phase

\begin{tabular}{cccc} 
Amine $\mathrm{N}^{\mathrm{o}}$ & Purity of $\mathbf{6 ( R )}(\%)^{\mathrm{a}}$ & ${\text { Yield of } \mathbf{6 ( R )}(\%)^{\mathrm{b}}}^{\mathrm{D} / \mathrm{H}(\%)^{\mathrm{b}}}$ \\
\hline $\mathbf{1 ( 1 )}$ & 62 & 66 & 38 \\
$\mathbf{1 ( 2 )}$ & 68 & 87 & 75 \\
$\mathbf{1 ( 4 )}$ & 88 & 70 & 68 \\
$\mathbf{1 ( 8 )}$ & 66 & 58 & 38 \\
$\mathbf{1 ( 1 5 )}$ & 90 & 60 & 46 \\
$\mathbf{1 ( 1 6 )}$ & 82 & 45 & 64 \\
$\mathbf{1 ( 1 7 )}$ & 68 & 15 & 60 \\
$\mathbf{1 ( 1 8 )}$ & 75 & 40 & 36 \\
$\mathbf{1 ( 1 9 )}$ & 78 & 36 & 60 \\
$\mathbf{1 ( 2 0 )}$ & 80 & 42 & 18
\end{tabular}

${ }^{\mathrm{a}}$ Determined via LC/MS analysis of the crude reaction mixture. ${ }^{\mathrm{b}}$ Determined by ${ }^{1} \mathrm{H}$ NMR.

\section{Immobilization of 1-methyl-2-aminoterephthalate on different resins and its deuteration}

The amine was immobilized to all resins according to the general procedure for immobilization of a substrate to Rink resin through $-\mathrm{CO}_{2} \mathrm{H}$ function (see S3). In case of immobilization to Wang resin, 0.3 equivalent of $N, N$-diisopropylethylamine was used as additional base. The deuteration was performed according to the general procedure for deuteration on solid-phase (see S18). The purities and deuterium contents are summarized in Table 2.

Table 2: Deamination/deuteration of 1-methyl-2-aminoterephthalate on different resins

$\begin{array}{cccccc}\text { Resin (mmol/g) } & \text { Cleaved product } & {[\mathrm{M}-\mathrm{H}]^{-} \text {calcd. }} & {[\mathrm{M}+\mathrm{H}]^{+} \text {found }} & \text { Purity (\%) } & \mathrm{D} / \mathrm{H}(\%) \\ \operatorname{Rink}(0.60) & 179.05 & \mathrm{ND} & 89 & 38\end{array}$




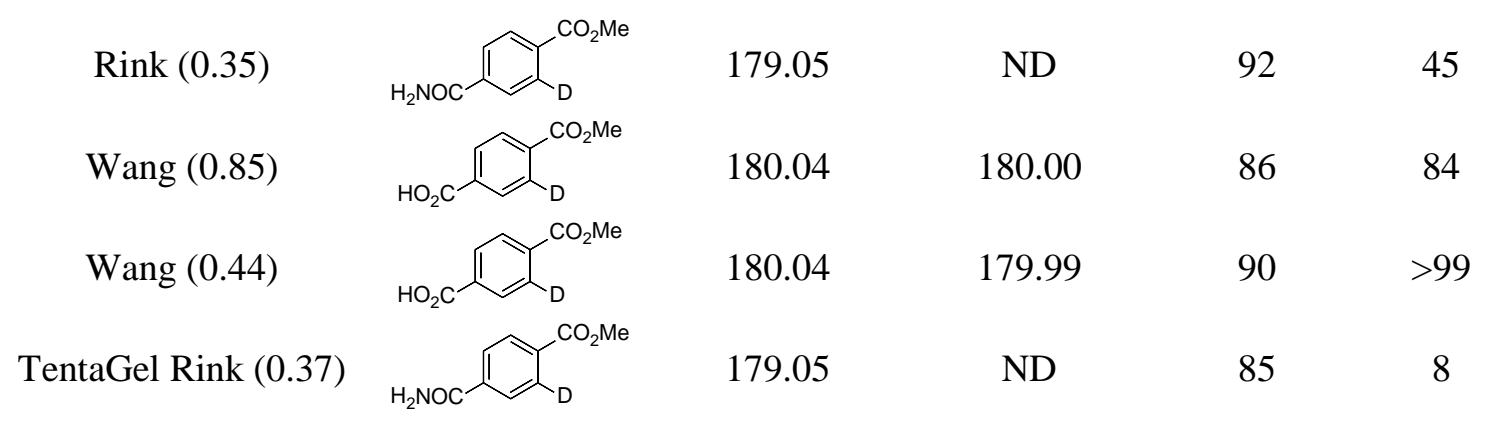

\section{Study of deamination/deuteration in solution}

For the study the commercially available amines $\mathbf{1 ( 2 1 )}-\mathbf{1}(\mathbf{2 7})$ were used. Amine $\mathbf{1 ( 2 8 )}$ was prepared according to the following scheme.

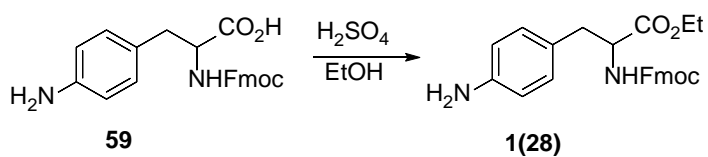

Amine 59 was prepared according to the published procedure ${ }^{3}$ with corresponding characterization data. The amine 59 (200 mg, $0.5 \mathrm{mmol}$ ) was then stirred in ethanol (3 ml) with $\mathrm{H}_{2} \mathrm{SO}_{4}(20 \mu \mathrm{L})$ for $3 \mathrm{~h}$ at $60{ }^{\circ} \mathrm{C}$. The solvent was evaporated to dryness to obtain amine 1(28). Yield: $212 \mathrm{mg}(99 \%) .{ }^{1} \mathrm{H}$ NMR (500 MHz, DMSO- $\left._{6}, \mathrm{ppm}\right) \delta: 7.78(\mathrm{~d}, J=7.5 \mathrm{~Hz}, 2 \mathrm{H}), 7.60(\mathrm{t}, J=7.5 \mathrm{~Hz}, 2 \mathrm{H}), 7.42$ (t, $\left.J=7.5 \mathrm{~Hz}, 2 \mathrm{H}\right), 7.33$ (t, $J$ $=7.5 \mathrm{~Hz}, 2 \mathrm{H}), 6.92(\mathrm{~d}, J=8.0 \mathrm{~Hz}, 2 \mathrm{H}), 6.59(\mathrm{~d}, J=8.0 \mathrm{~Hz}, 2 \mathrm{H}), 5.56(\mathrm{~d}, J=8.5 \mathrm{~Hz}, 1 \mathrm{H}), 4.65-4.61$ (m, 1H), 4.46 - 4.35 (m, 2H), $4.24-4.17$ (m, 3H), 3.61 (br, 2H), $3.07-2.99$ (m, 2H), 1.26 (t, $J=7.5$ Hz, 3H). ${ }^{13} \mathrm{C}$ NMR (126 MHz, D2O, ppm) $\delta: 171.7,155.6,145.4,143.7,141.2,130.0,127.6,126.9,125.2$, 125.0, 119.9, 115.1, 66.7, 61.3, 55.0, 47.0, 37.3, 30.7, 14.0. LC/MS analysis: MS (ESI) exact mass calcd. for $\mathrm{C}_{26} \mathrm{H}_{27} \mathrm{~N}_{2} \mathrm{O}_{4}[\mathrm{M}+\mathrm{H}]^{+}$: 431.19; found: 431.17, $\mathrm{t}_{\mathrm{R}}=3.33$ min, purity: 99\%.

\section{General procedure for deamination/deuteration in solution}

Amine (20 mg) and $\mathrm{NaNO}_{2}(69 \mathrm{mg}, 1 \mathrm{mmol})$ were dissolved in mixture of $\mathrm{CHCl}_{3}$ or $\mathrm{CDCl}_{3}(1 \mathrm{~mL}), \mathrm{H}_{2} \mathrm{O}$ $(1 \mathrm{~mL})$ and $\mathrm{AcOH}(0.2 \mathrm{~mL})$. The mixture was stirred $0.5 \mathrm{~h}$ at room temperature and the organic layer was 
separated and analyzed without further purification. Purity was determined by LC/MS analysis with PDA detector. Yield was determined via LC/MS analysis of the crude reaction mixture according to the calibration curve of an appropriate standard. Yields, purities and deuterium contents are summarized in Table 3. The derivatives $\mathbf{1 ( 2 1 )}$ and $\mathbf{1 ( 2 2 )}$ were decomposed during the reaction with $\mathrm{CHCl}_{3}$ as weel as $\mathrm{CDCl}_{3}$. Derivative $\mathbf{1}(\mathbf{2 6})$ was decomposed during reaction with $\mathrm{CDCl}_{3}$.

Table 3: Deamination/deuteration of amines $\mathbf{1}(\mathbf{R})$ in solution

\begin{tabular}{|c|c|c|c|c|}
\hline $\begin{array}{l}\text { Amine } \\
\mathrm{N}^{\mathrm{O}}\end{array}$ & $\begin{array}{l}\text { Purity of product } \mathbf{2 ( R ) ^ { \mathrm { a } }} \\
(\%)\end{array}$ & $\begin{array}{l}\text { Yield of product } \mathbf{2 ( \mathbf { R } )}{ }^{\mathrm{b}} \\
(\%)\end{array}$ & $\begin{array}{l}\text { Yield of product } \mathbf{6}(\mathbf{R})^{\mathrm{c}} \\
(\%)\end{array}$ & $\begin{array}{c}\mathrm{D} / \mathrm{H} \text { in } \mathbf{6}(\mathbf{R})^{\mathrm{C}} \\
(\%)\end{array}$ \\
\hline 1(23) & 62 & 66 & 51 & $>99$ \\
\hline $1(24)$ & 68 & 87 & 43 & $>99$ \\
\hline 1(25) & 88 & 70 & 50 & $>99$ \\
\hline 1(26) & 66 & 58 & - & - \\
\hline $\mathbf{1}(27)$ & 90 & 60 & 49 & $>99$ \\
\hline $1(28)$ & - & - & 60 & $>99$ \\
\hline
\end{tabular}

${ }^{a}$ Determined via LC/MS analysis. ${ }^{b}$ Determined via LC/MS analysis of the crude reaction mixture according to the calibration curve of an appropriate standard. ${ }^{\mathrm{C}}$ Determined by ${ }^{1} \mathrm{H}$ NMR.

6(23)

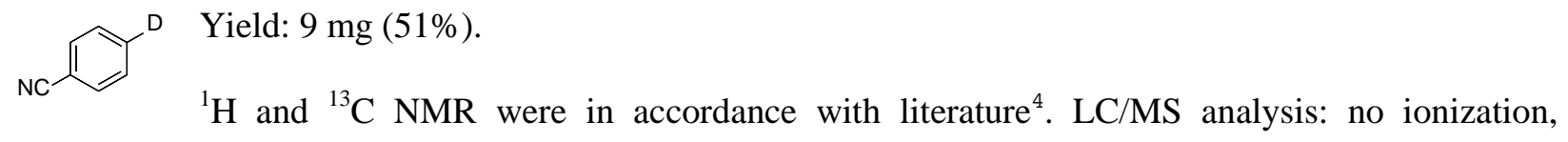
comparison with benzonitrile as standard, $t_{R}=1.94$ min, crude purity: $34 \%$. Isotopic purity: > 99\%.

6(24)

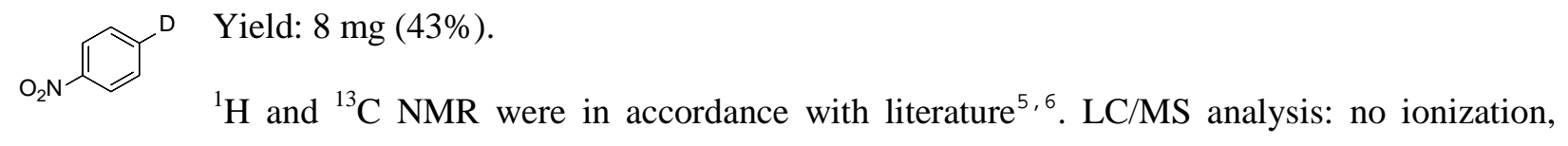
comparison with nitrobenzen as standard, $\mathrm{t}_{\mathrm{R}}=2.58 \mathrm{~min}$, crude purity: 39\%. Isotopic purity: > 99\%.

6(25)

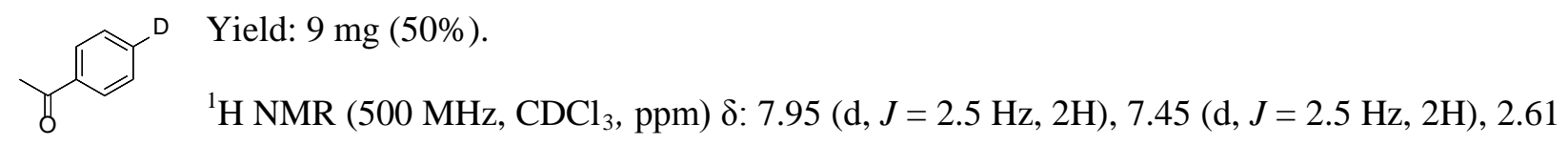


(s, 3H). ${ }^{13} \mathrm{C}$ NMR in accordance with literature ${ }^{5}$. LC/MS analysis: no ionization, comparison with acetophenone as standard, $\mathrm{t}_{\mathrm{R}}=2.22 \mathrm{~min}$, crude purity: 57\%. Isotopic purity: $>99 \%$.

6(27)

$\mathrm{CO}_{2} \mathrm{Me} \quad$ Yield: $9 \mathrm{mg}(49 \%)$.

${ }^{1} \mathrm{H}$ and ${ }^{13} \mathrm{C}$ NMR were in accordance with literature ${ }^{7}$. LC/MS analysis: MS (ESI) exact mass calcd. for $\mathrm{C}_{8} \mathrm{H}_{8} \mathrm{D}_{1} \mathrm{O}_{2}[\mathrm{M}+\mathrm{H}]^{+}: 136.07$; found: $136.07, \mathrm{t}_{\mathrm{R}}=2.58$ min, crude purity: 65\%. Isotopic purity: > $99 \%$.

6(28)

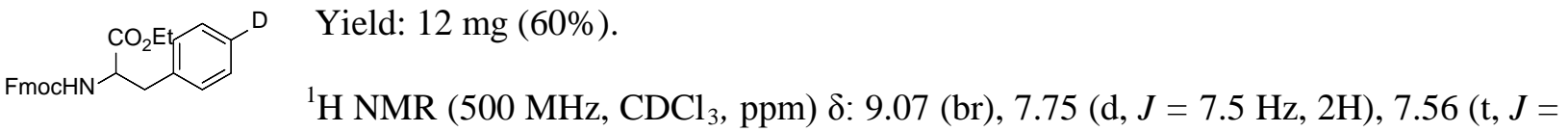
$7.5 \mathrm{~Hz}, 2 \mathrm{H}), 7.39$ (t, $J=7.5 \mathrm{~Hz}, 2 \mathrm{H}), 7.32-7.24$ (m, 4H), 7.10 (d, $J=8.0 \mathrm{~Hz}, 2 \mathrm{H}), 5.40$ (d, $J=8.5 \mathrm{~Hz}$, 1H), $4.68-4.62(\mathrm{~m}, 1 \mathrm{H}), 4.46-4.41(\mathrm{~m}, 1 \mathrm{H}), 4.35-4.30(\mathrm{~m}, 1 \mathrm{H}), 4.21-4.13(\mathrm{~m}, 3 \mathrm{H}), 3.15-3.08$ (m, 1H), 1.23 (t, $J=7.5 \mathrm{~Hz}, 3 \mathrm{H}) .{ }^{13} \mathrm{C}$ NMR $\left(126 \mathrm{MHz}, \mathrm{CDCl}_{3}, \mathrm{ppm}\right) \delta: 171.7,155.7,143.8,143.7,141.2$, 135.7, 129.3, 128.4, 127.7, 127.0, $126.8\left(\mathrm{t}, J_{C D}=24 \mathrm{~Hz}\right), 125.1,125.0,120.0,119.9,66.9,61.6,54.8$, 47.1, 38.2, 14.0. HRMS (ESI+) m/z: [M+1] calcd for $\mathrm{C}_{26} \mathrm{H}_{25} \mathrm{DNO}_{4}$ 417.1919; found: 417.1918. Isotopic purity: $>99 \%$.

\section{Radical capturing experiments}

29

Acetonitrile $(2.5 \mathrm{~mL})$ and solution of sodium ascorbate (50 mg, $0.3 \mathrm{mmol})$ in DMSO $(0.3 \mathrm{~mL})$ was added. After $1 \mathrm{~h}$ of stirring under inert atmosphere at room temperature, $t$-BuONO (0.09 $\mathrm{mL}, 0.7 \mathrm{mmol}$ ) was added and the mixture was stirred $6 \mathrm{~h}$ at room temperature. Purification of the crude product was achieved by HPLC. 
Yield: $75 \mathrm{mg}$ (45\%). ${ }^{1} \mathrm{H}$ NMR (500 MHz, $\left.\mathrm{CDCl}_{3}, \mathrm{ppm}\right) \delta: 8.43$ (s, 1H), 7.80 (d, $\left.J=8 \mathrm{~Hz}, 1 \mathrm{H}\right), 7.59$ (d, $J$ = $8 \mathrm{~Hz}, 1 \mathrm{H}), 3.94(\mathrm{~s}, 3 \mathrm{H}), 1.72-1.57(\mathrm{~m}, 5 \mathrm{H}), 1.46-1.42(\mathrm{~m}, 1 \mathrm{H}), 1.29(\mathrm{~s}, 6 \mathrm{H}) .{ }^{13} \mathrm{C}$ NMR $(126 \mathrm{MHz}$, $\left.\mathrm{CDCl}_{3}, \mathrm{ppm}\right) \delta: 171.4,166.6,133.4,131.1,121.0,117.7,61.1,52.3,39.7,32.4,20.9,17.1$. LC/MS analysis: MS (ESI) exact mass calcd. for $\mathrm{C}_{18} \mathrm{H}_{14} \mathrm{NO}_{5}[\mathrm{M}-\mathrm{H}]^{-}$: 334.17; found: 334.08, $\mathrm{t}_{\mathrm{R}}=2.04$ min, purity: 99\%.

30

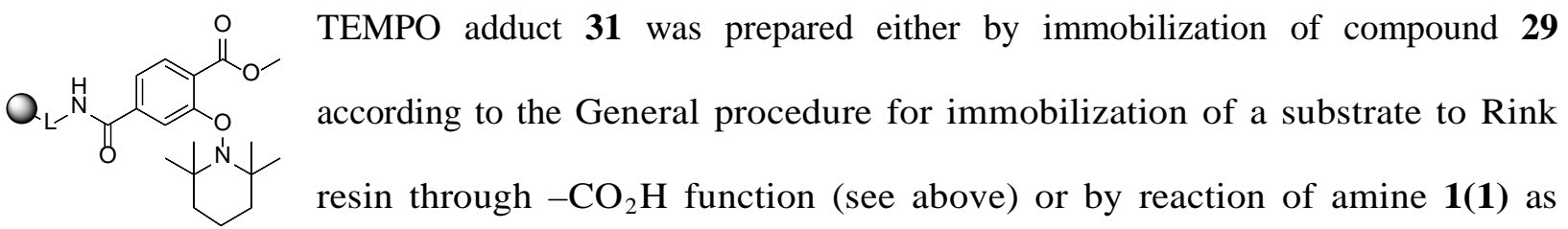
follows: Resin (300 mg) bearing immobilized amine 1(1) was treated with mixture of $\mathrm{NaNO}_{2}(140 \mathrm{mg}$, $2.0 \mathrm{mmol})$, AcOH (0.4 ml), TEMPO (625 mg, $4 \mathrm{mmol})$, DCM (2 mL) and water (2 mL). The resulting mixture was stirred vigorously for $30 \mathrm{~min}$ at room temperature. Finally, the resin was washed with mixture of DCM and water (3x4 mL), DMF (3x4 mL) and DCM (3x4 mL). The product was cleaved from the resin in form of phenol derivative 31. LC/MS analysis: MS (ESI) exact mass calcd. for $\mathrm{C}_{9} \mathrm{H}_{8} \mathrm{NO}_{4}[\mathrm{M}-\mathrm{H}]^{-}: 194.05$; found: 194.12, $\mathrm{t}_{\mathrm{R}}=2.04$ min, purity: $60 \%$. 


\section{${ }^{1} \mathrm{H}$ and ${ }^{13} \mathrm{C}$ NMR spectra}

1(28)
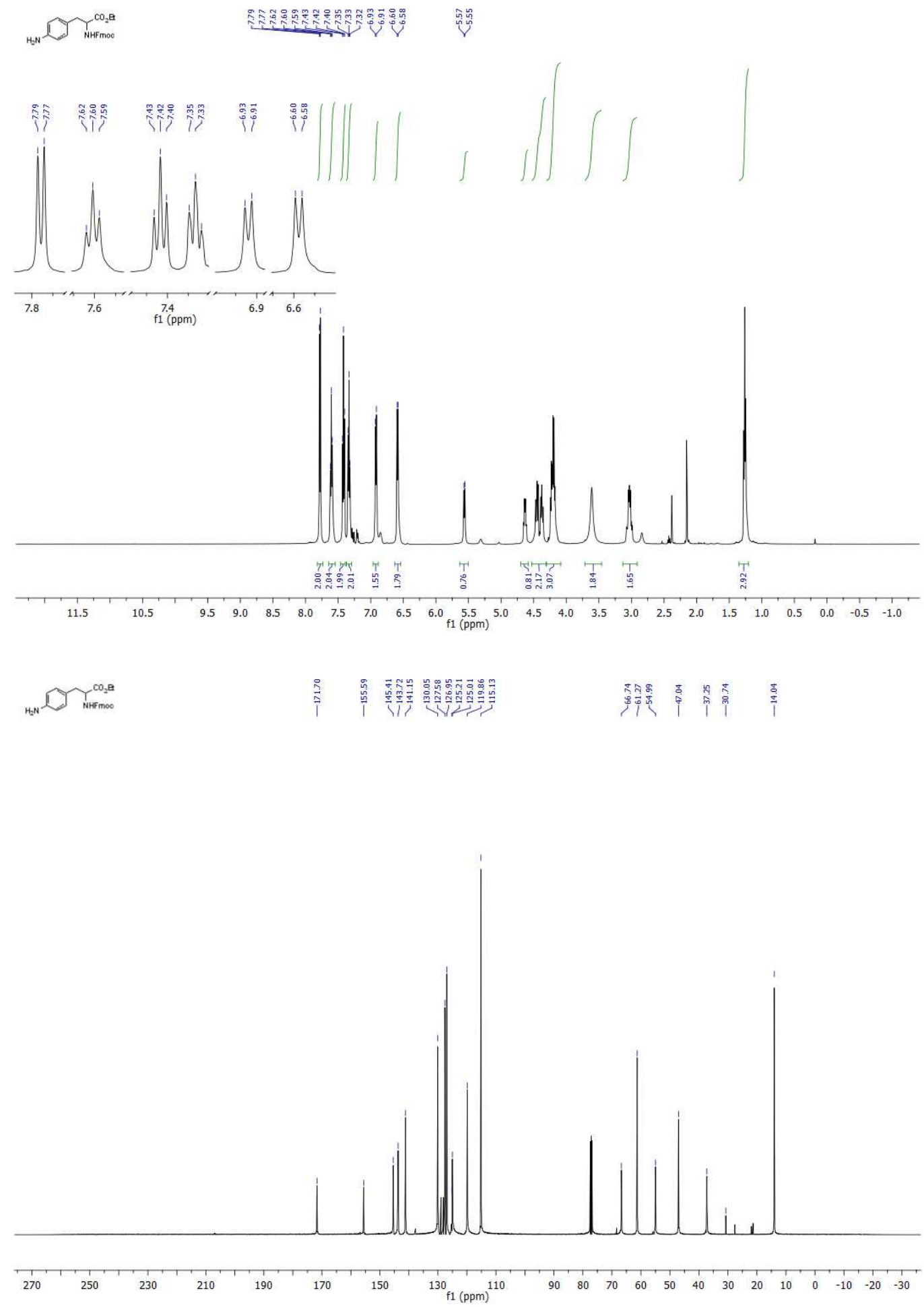

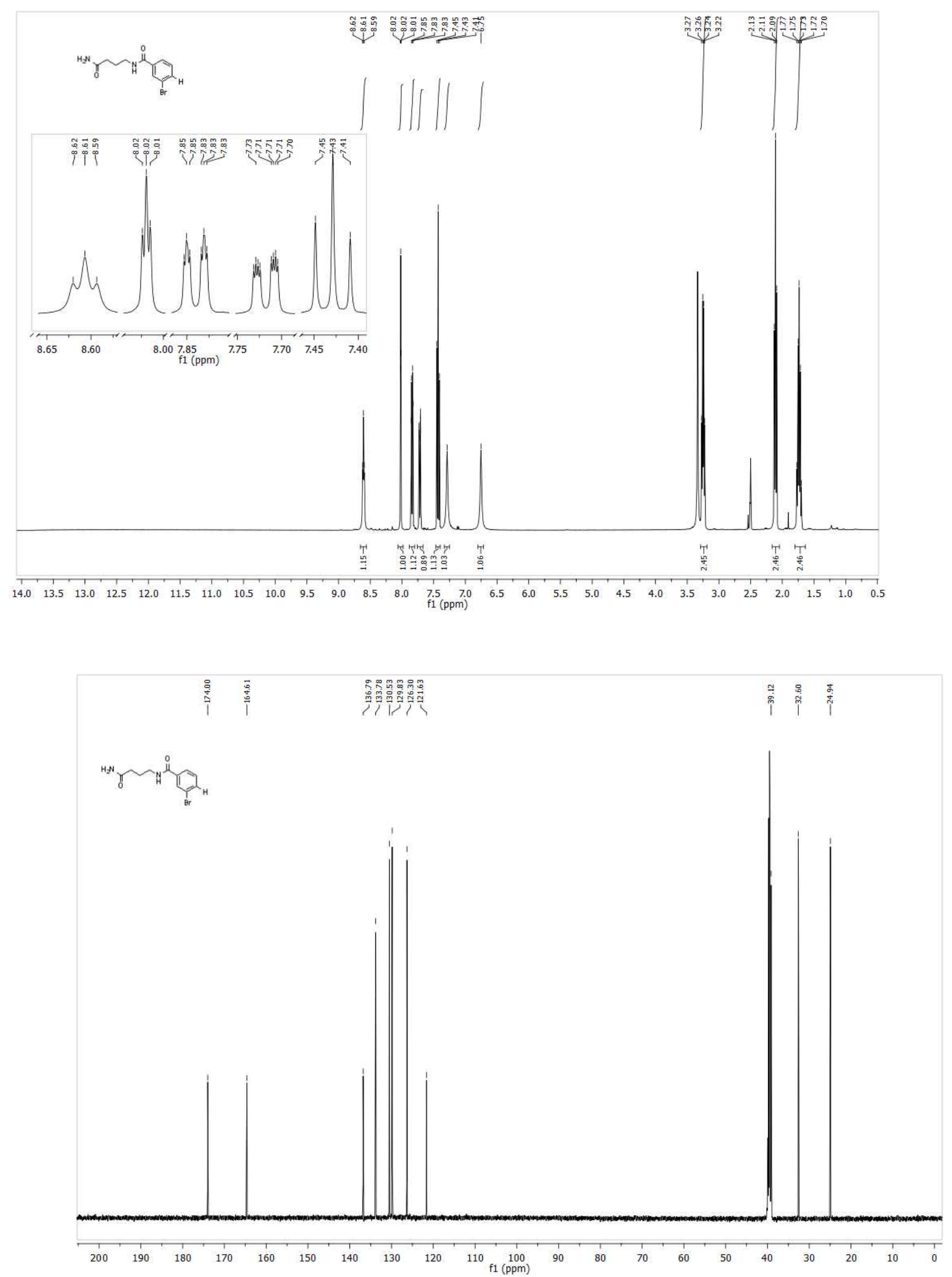

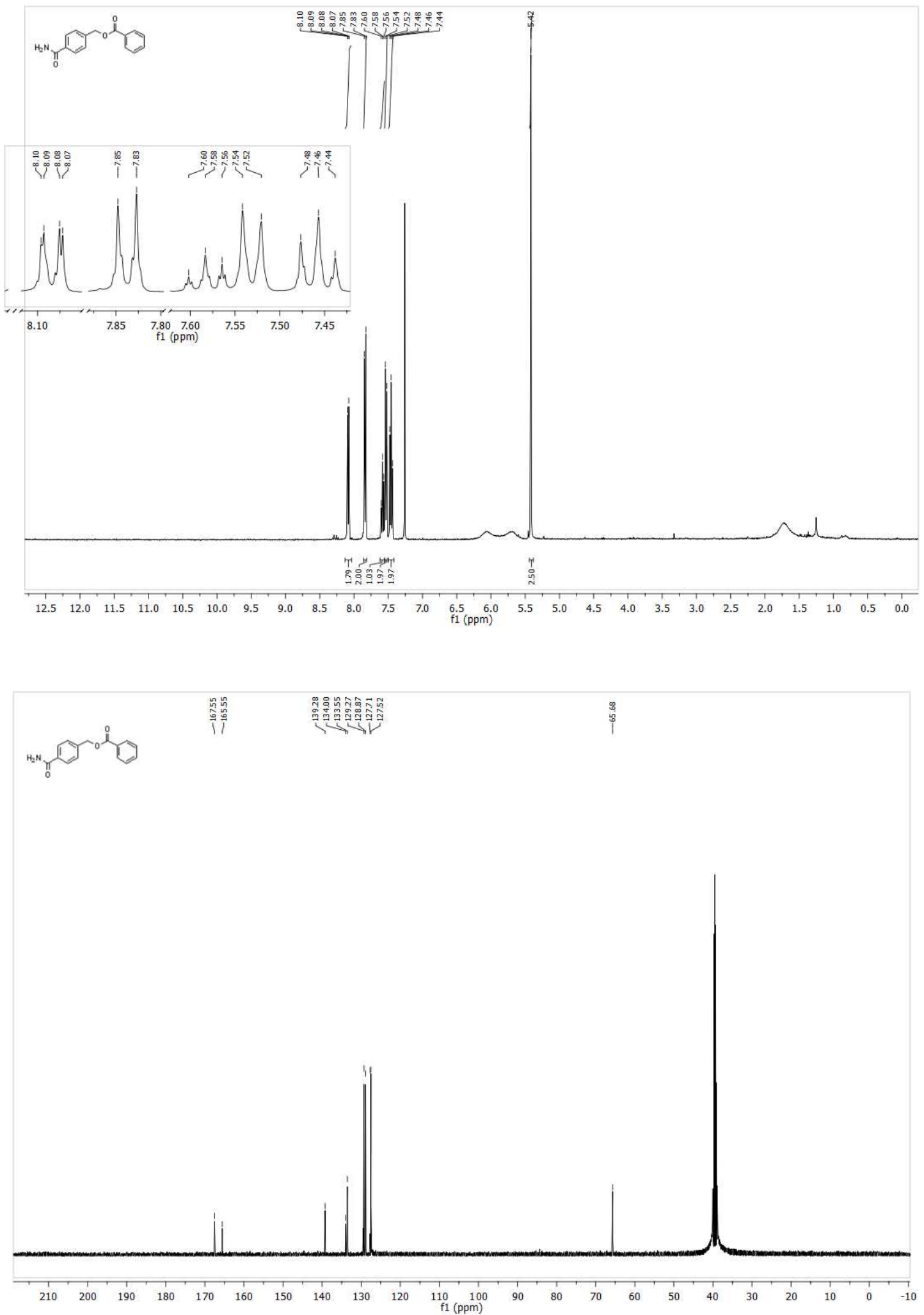

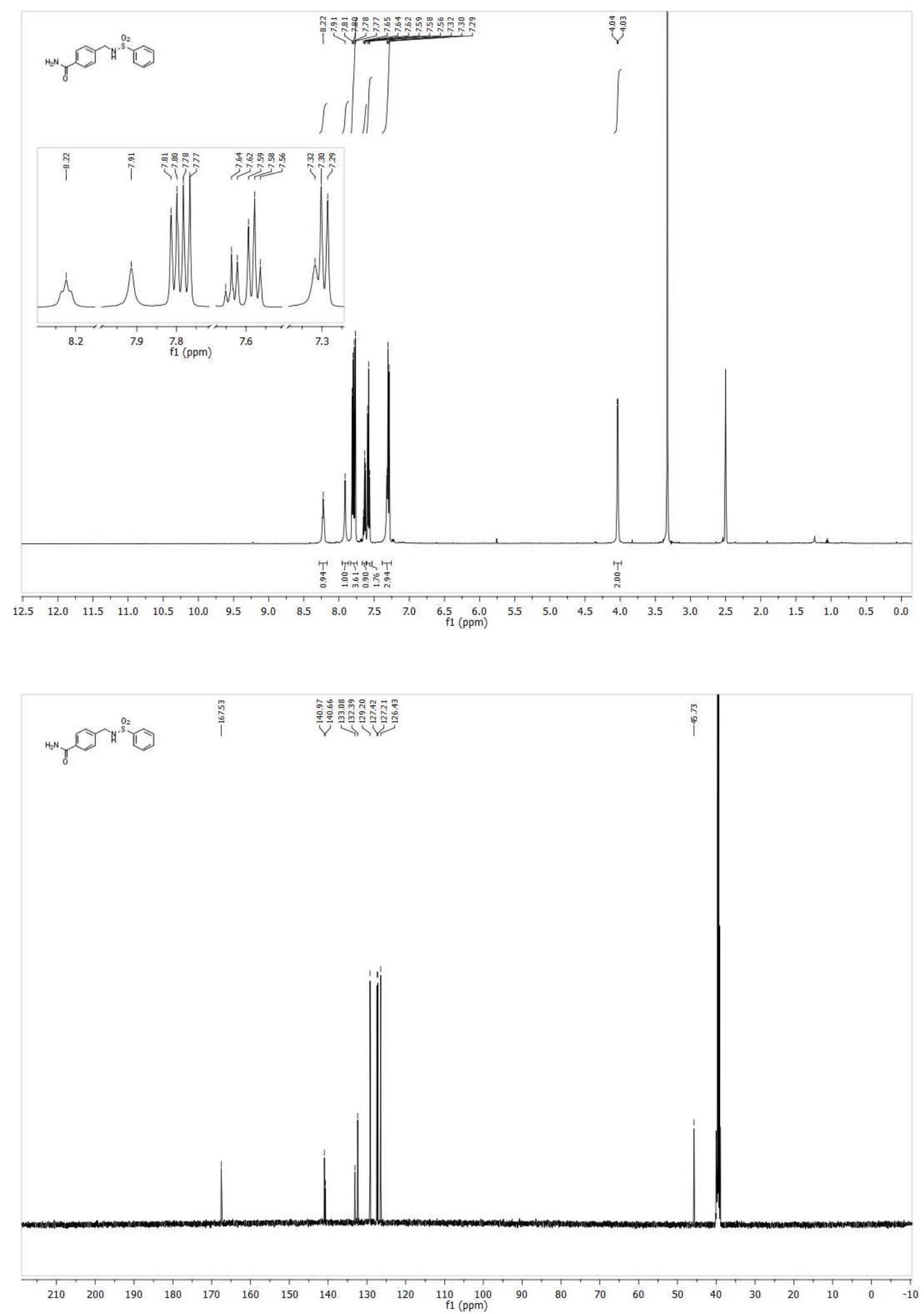

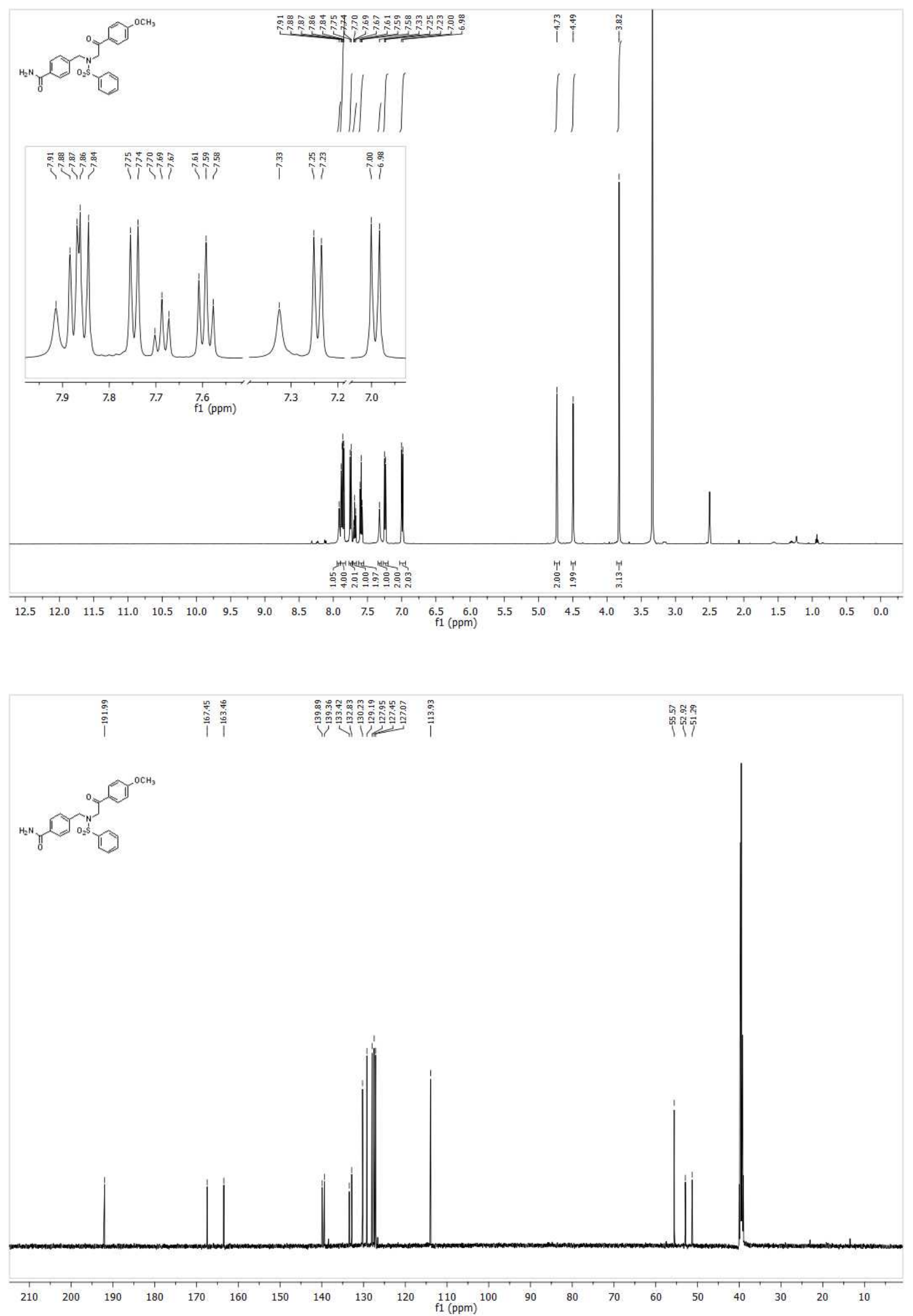
2(6)

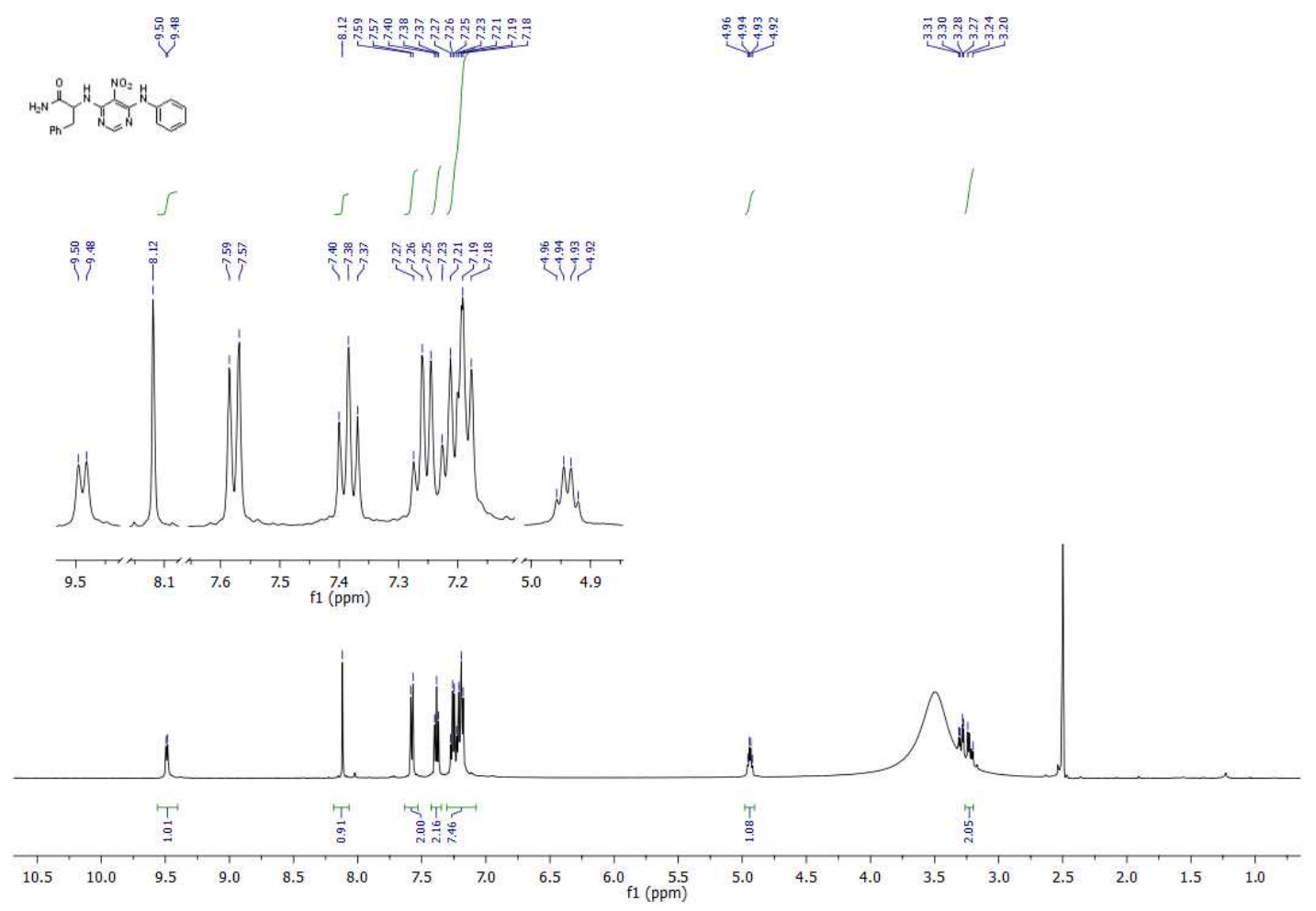

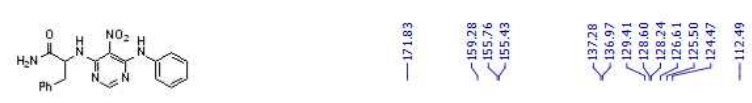

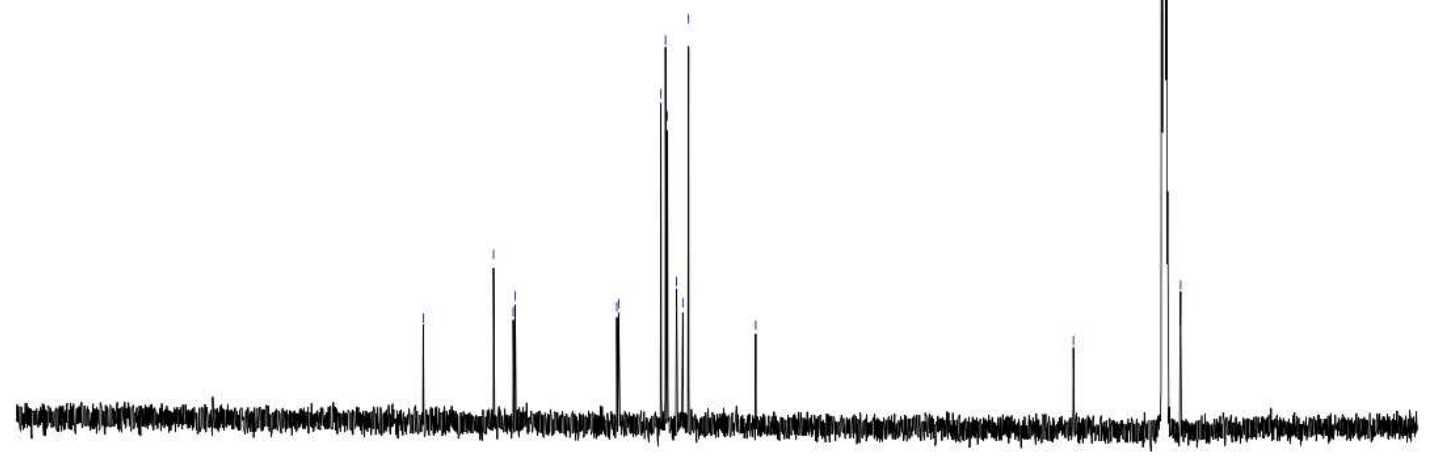

\begin{tabular}{lllllllllllllllllllllllllll}
\hline & 240 & 230 & 220 & 210 & 200 & 190 & 180 & 170 & 160 & 150 & 140 & 130 & 120 & 110 & 100 & 90 & 80 & 70 & 60 & 50 & 40 & 30 & 20 & 10 & 0
\end{tabular} 

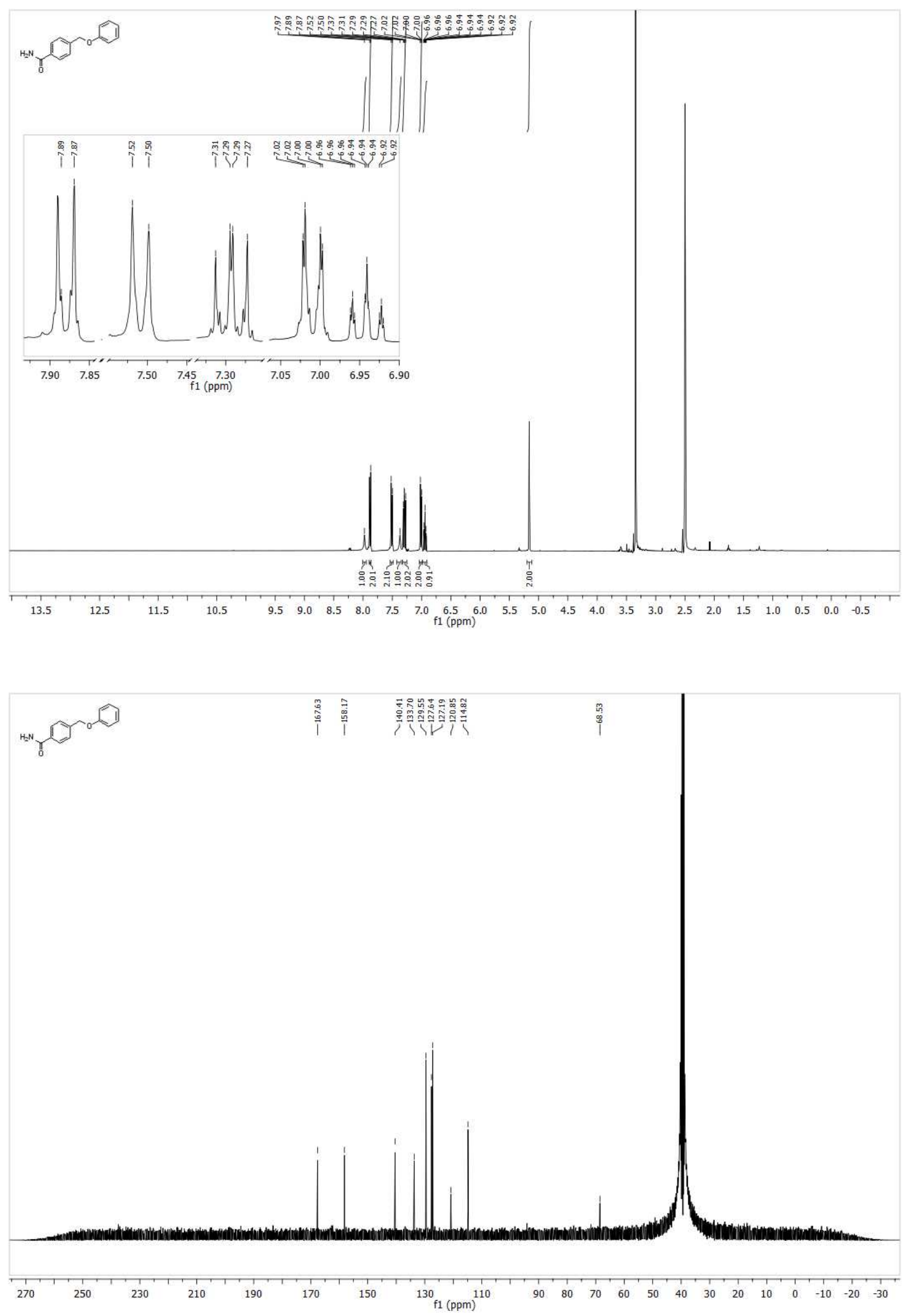

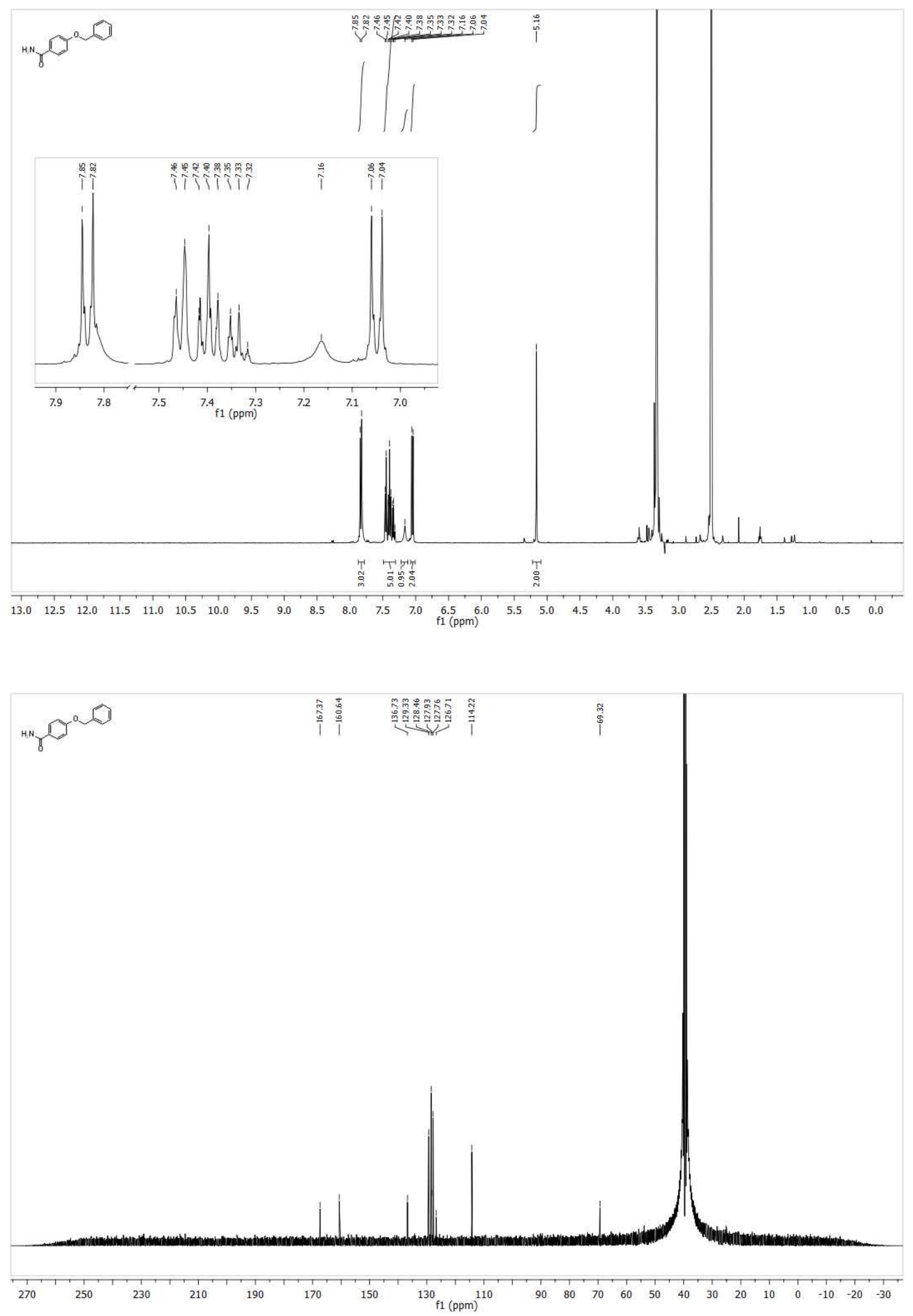


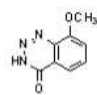

maํ.

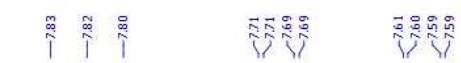
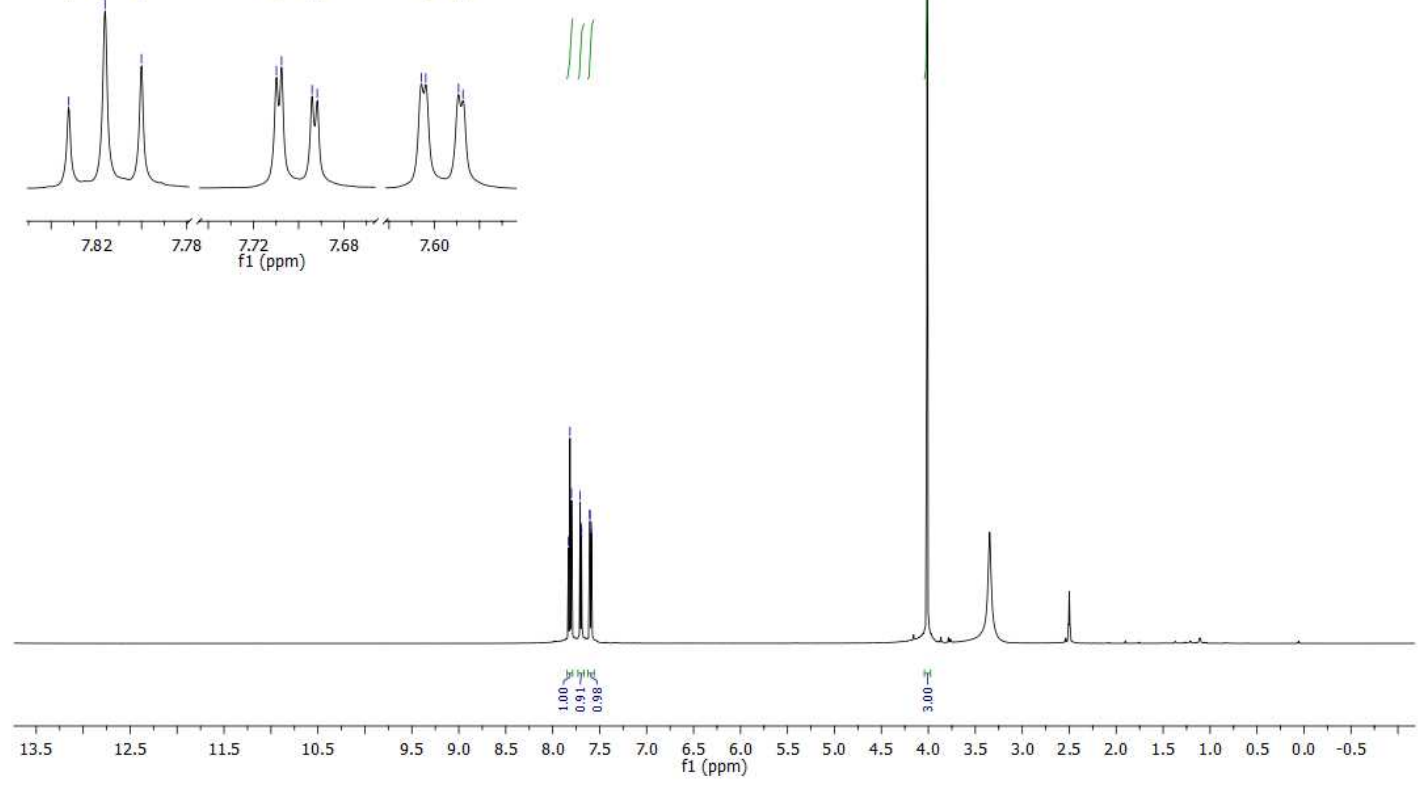

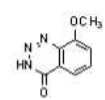

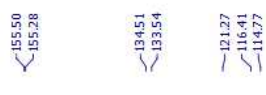

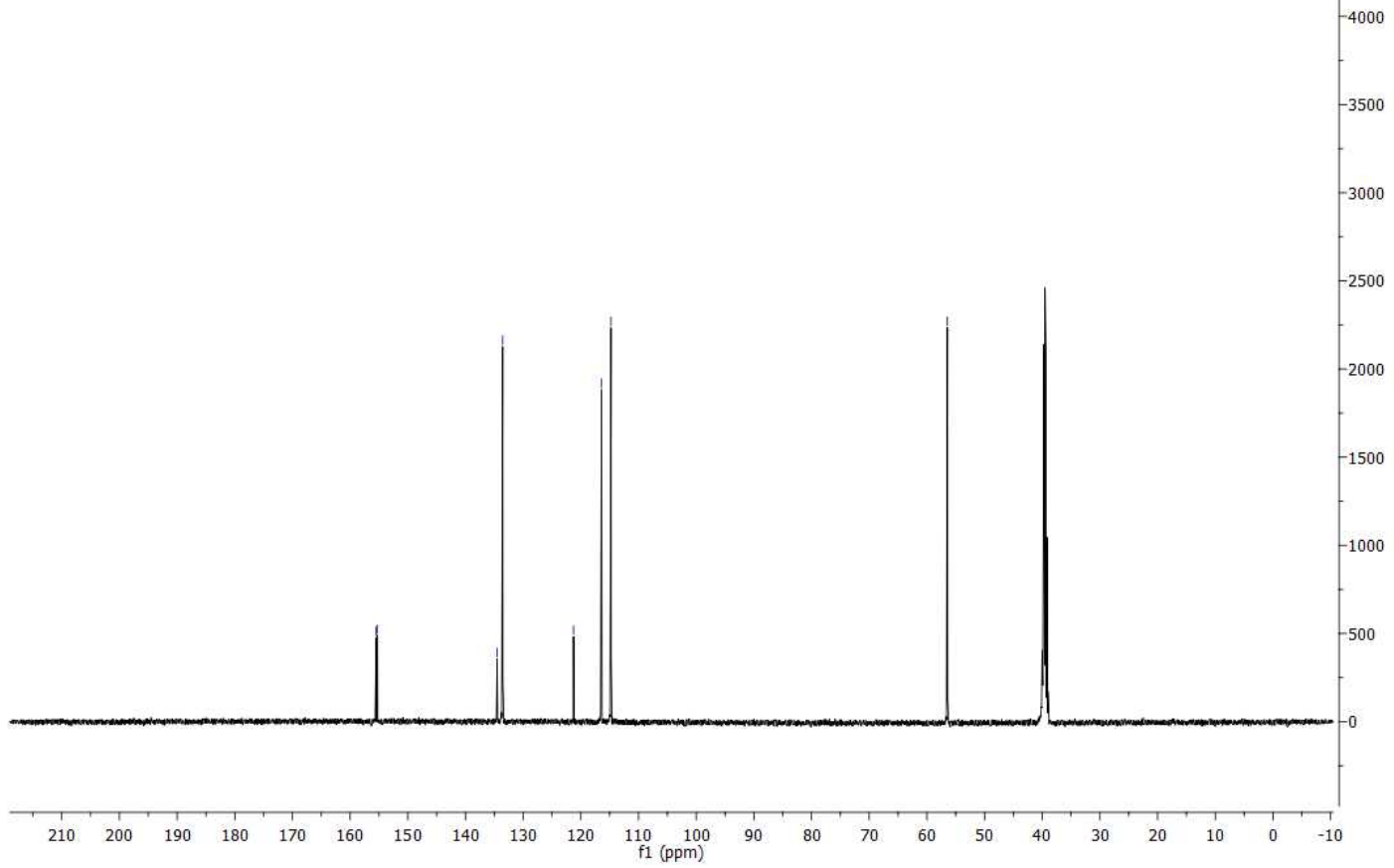




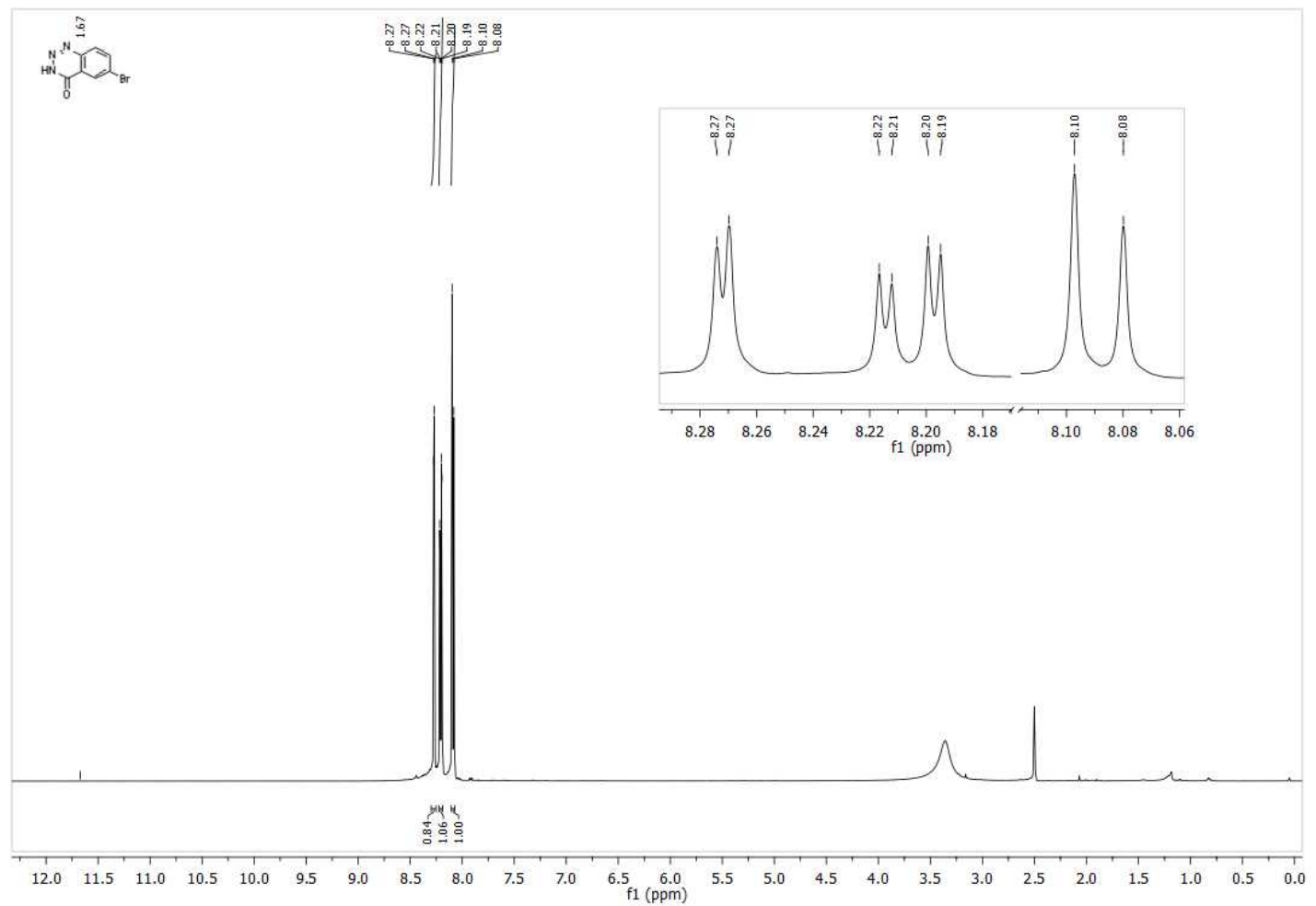

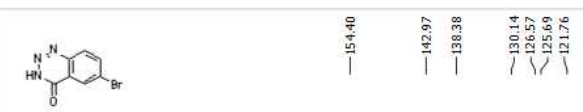

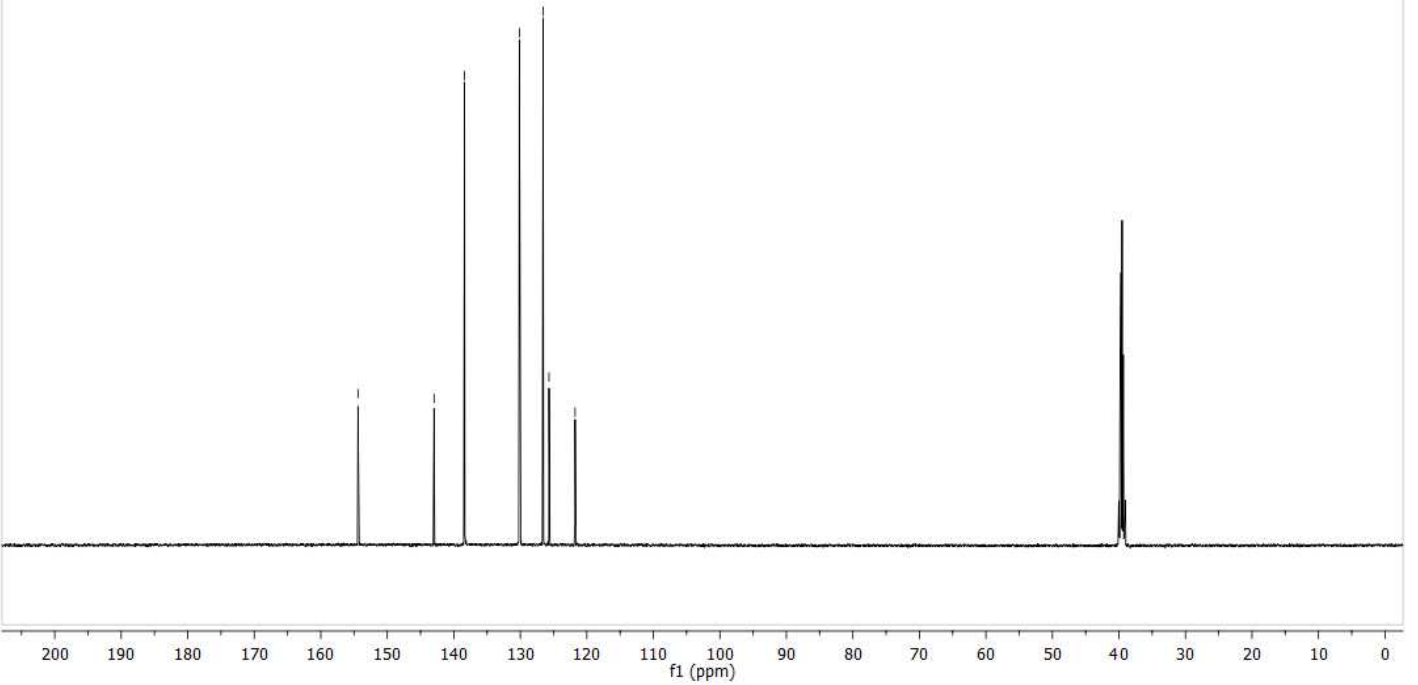



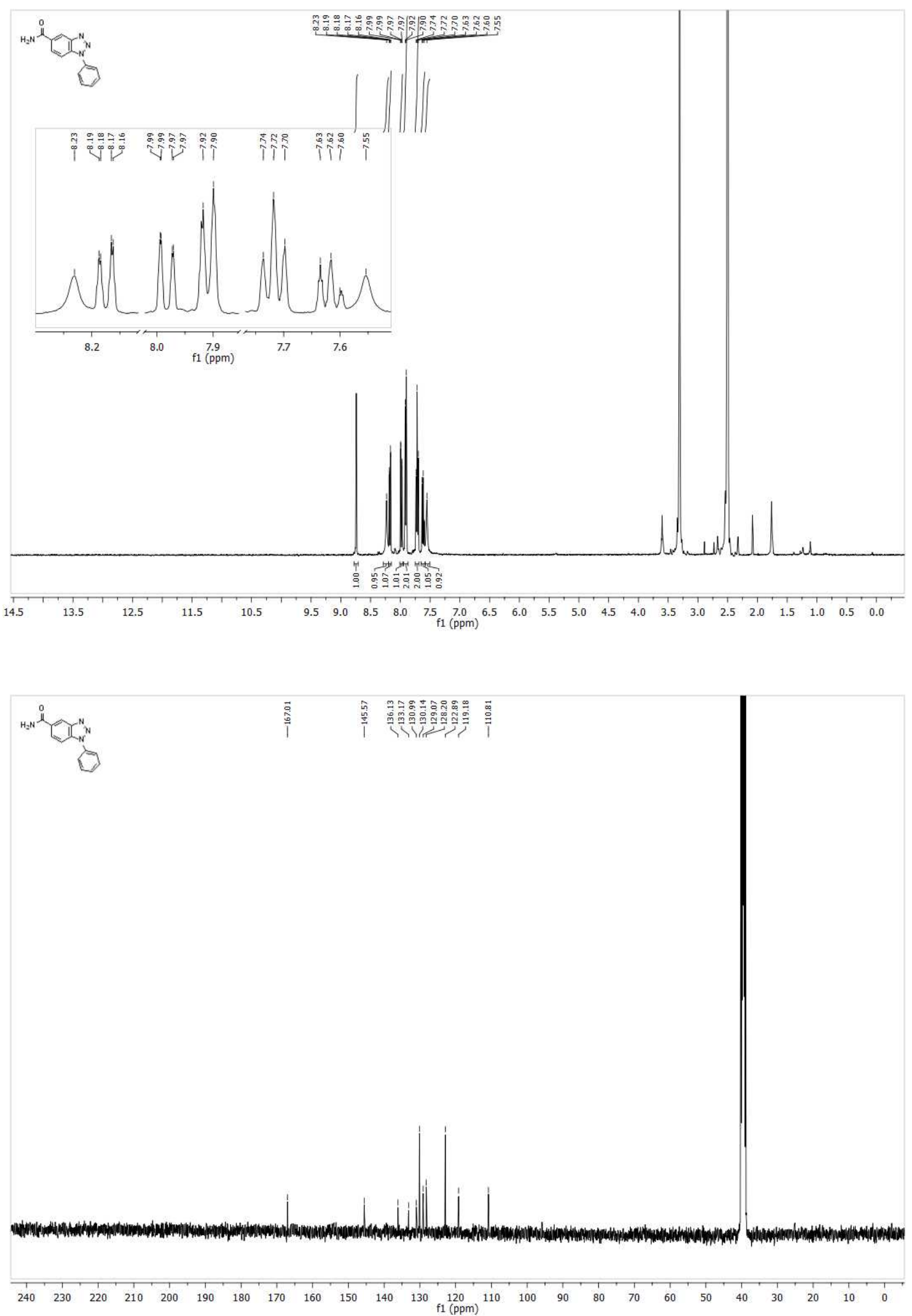
6(24) $-{ }^{13} \mathrm{C}$ NMR spectrum of crude reaction mixture

$$
\mathbb{O}^{0}
$$

인
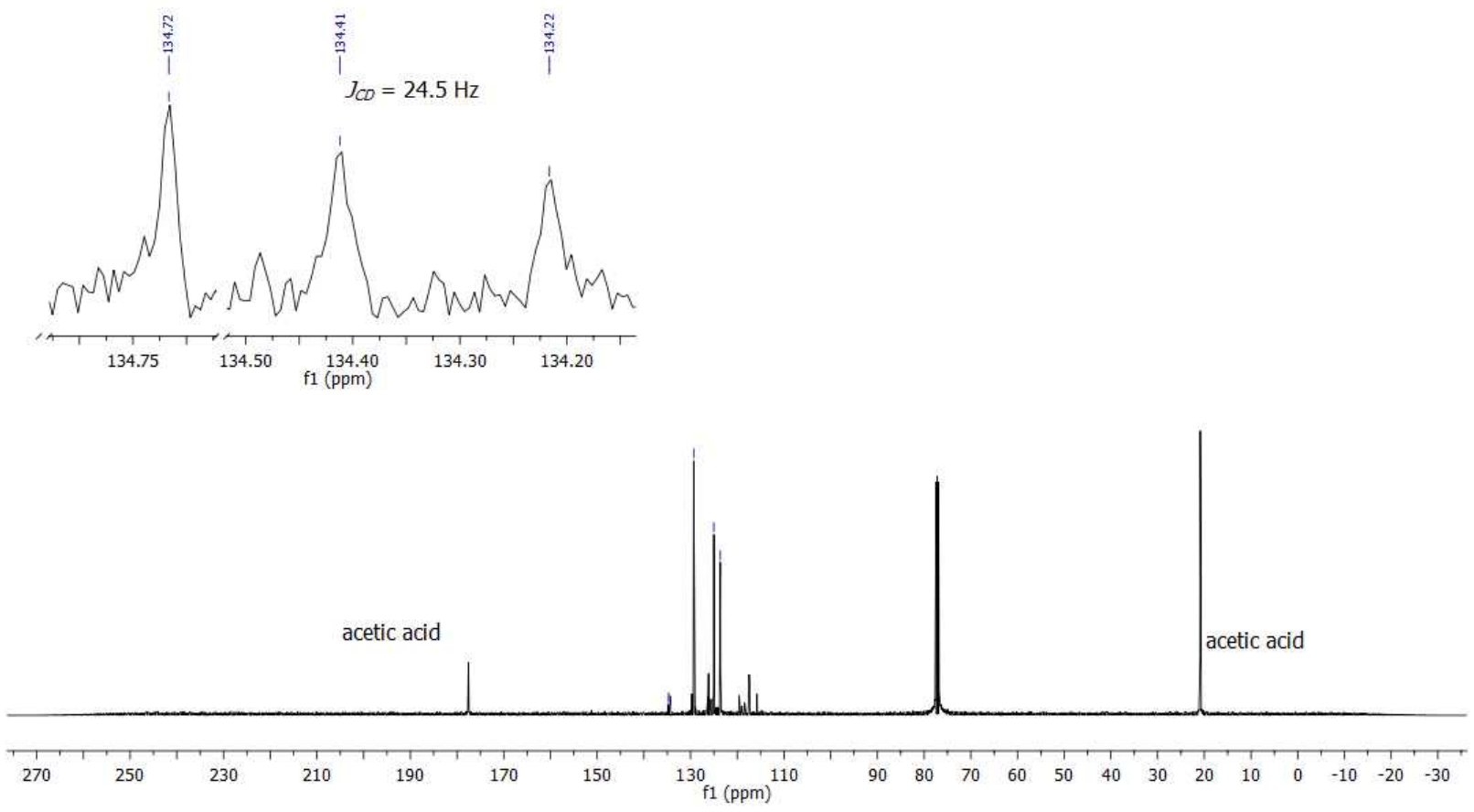
6(25) - NMR spectra of crude reaction mixture
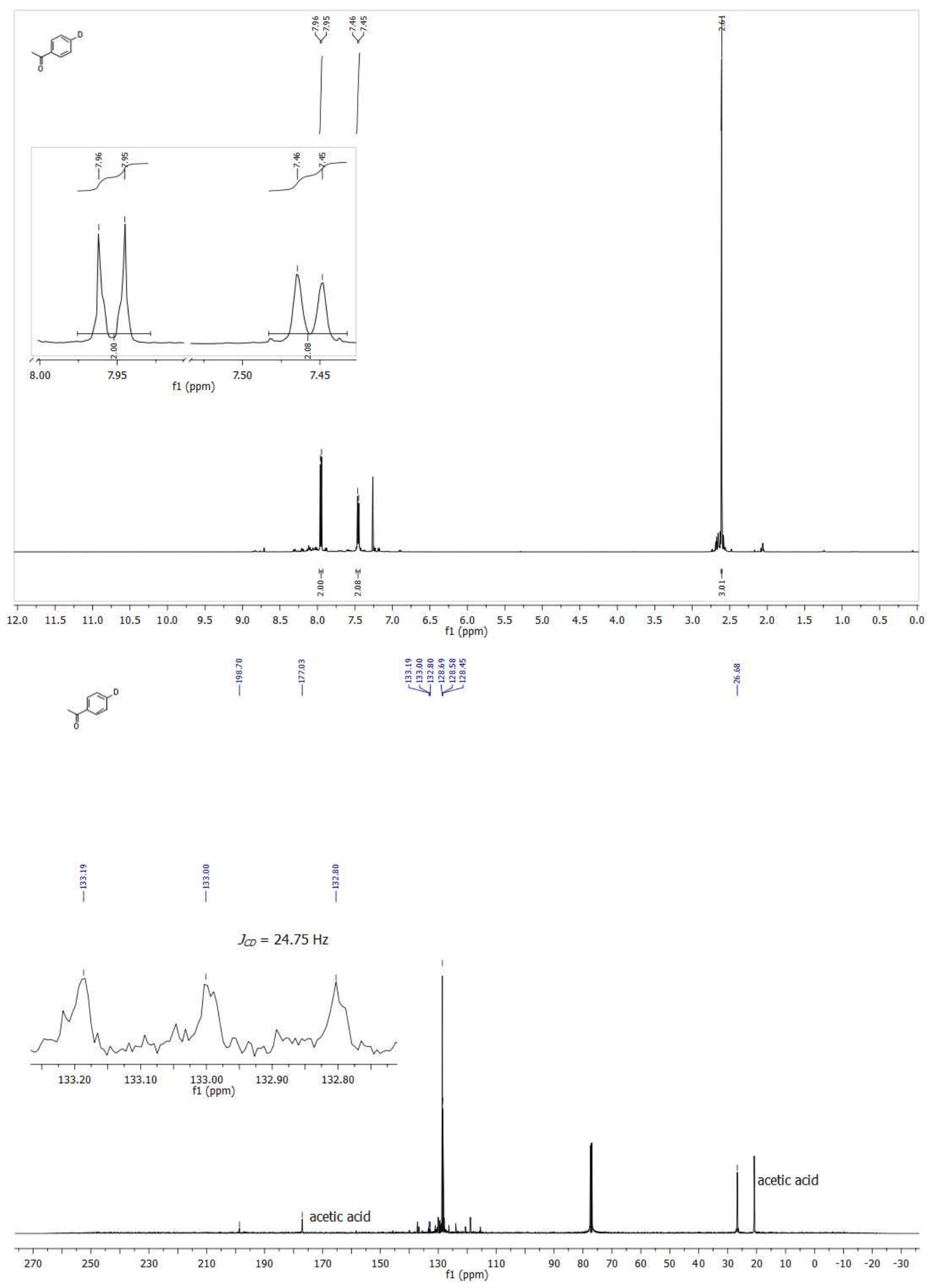
6(27) $-{ }^{13} \mathrm{C}$ NMR spectrum of crude reaction mixture
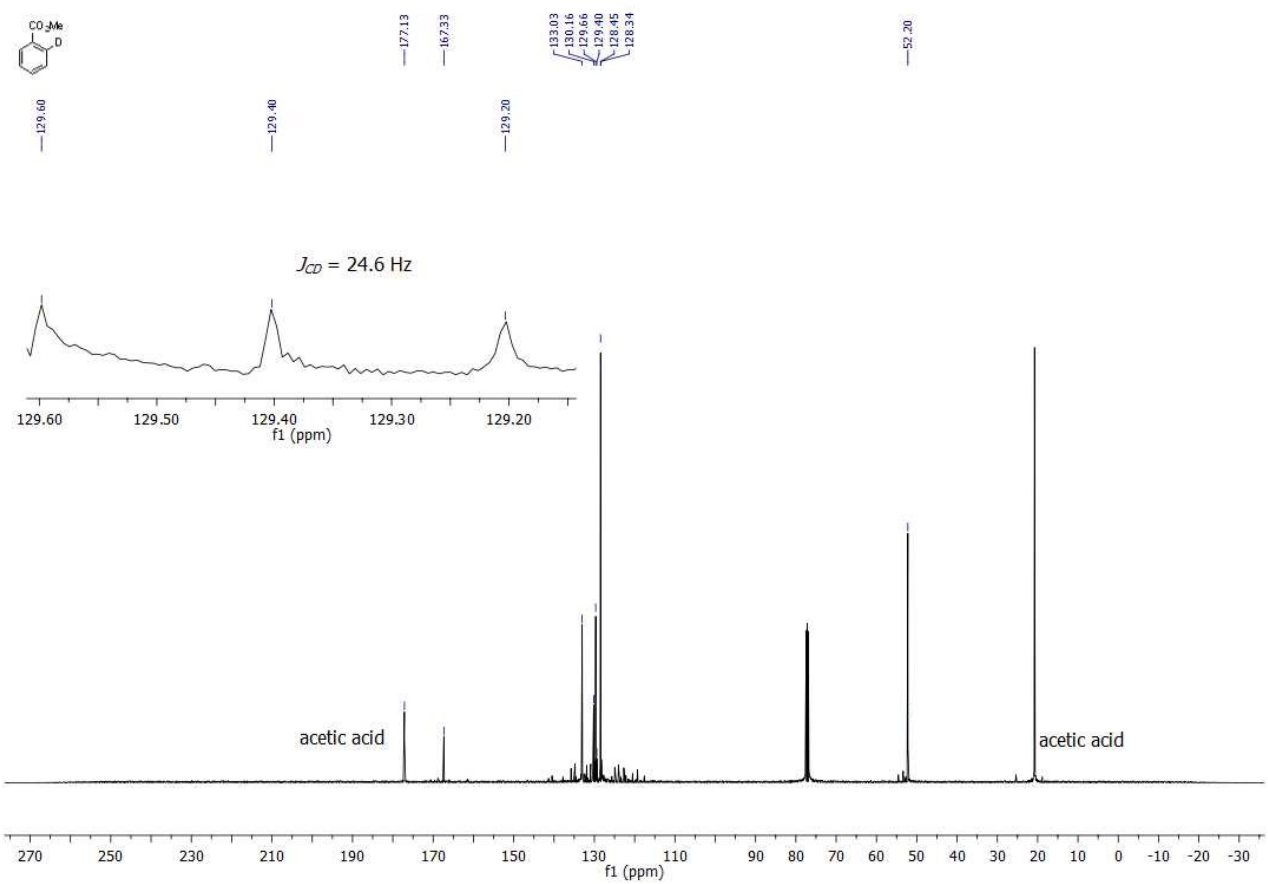
6(28) - NMR spectra of crude reaction mixture

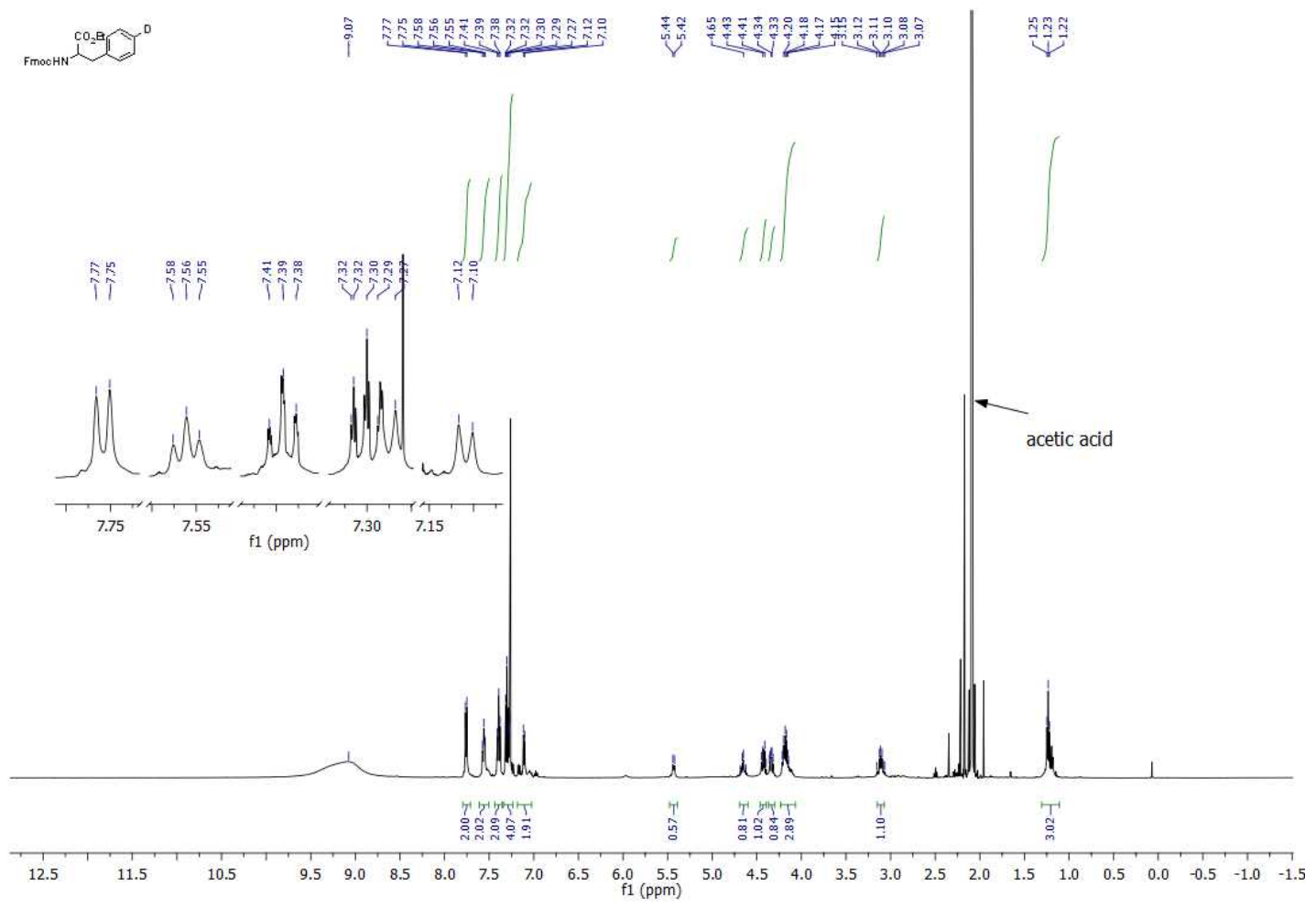




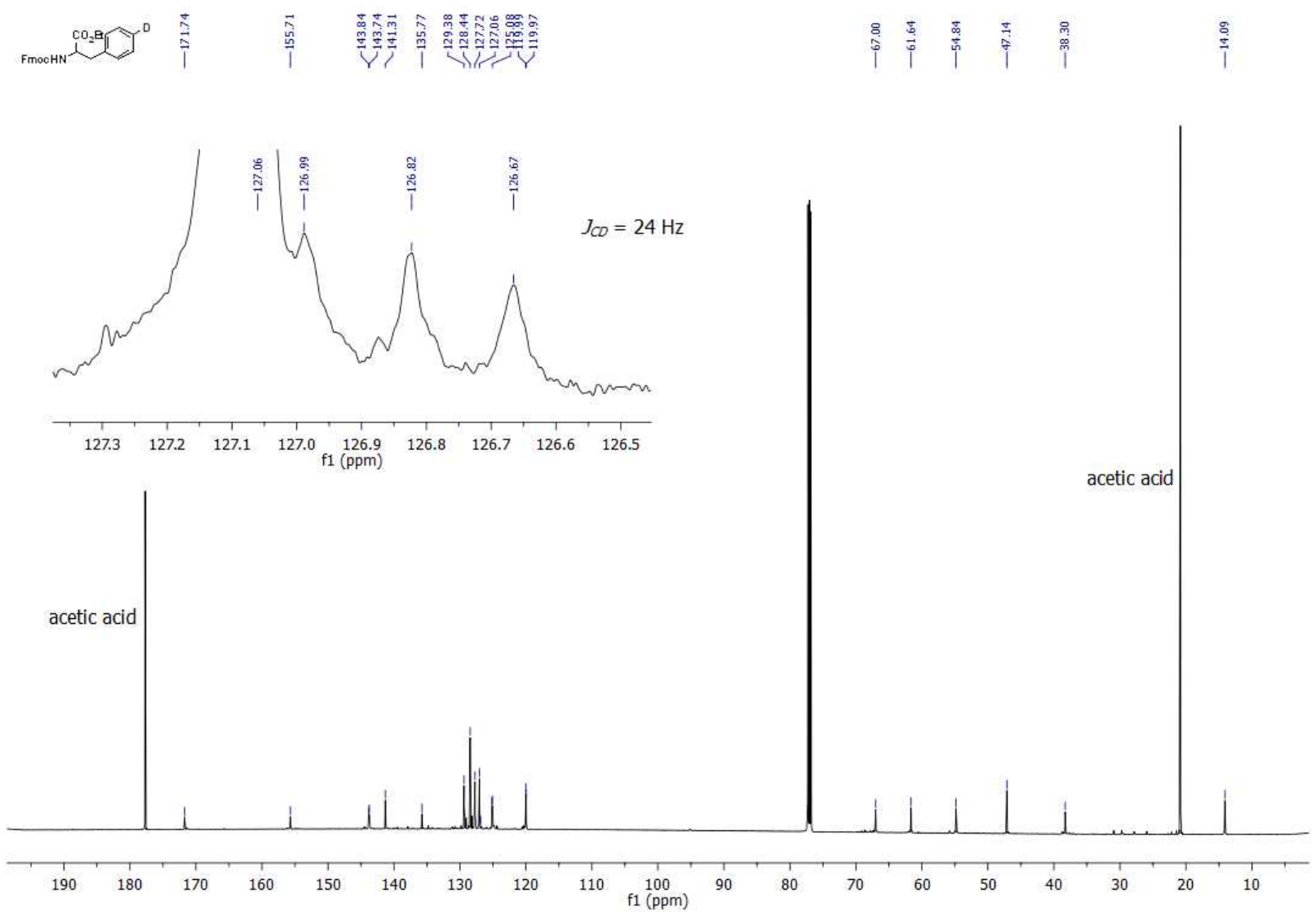



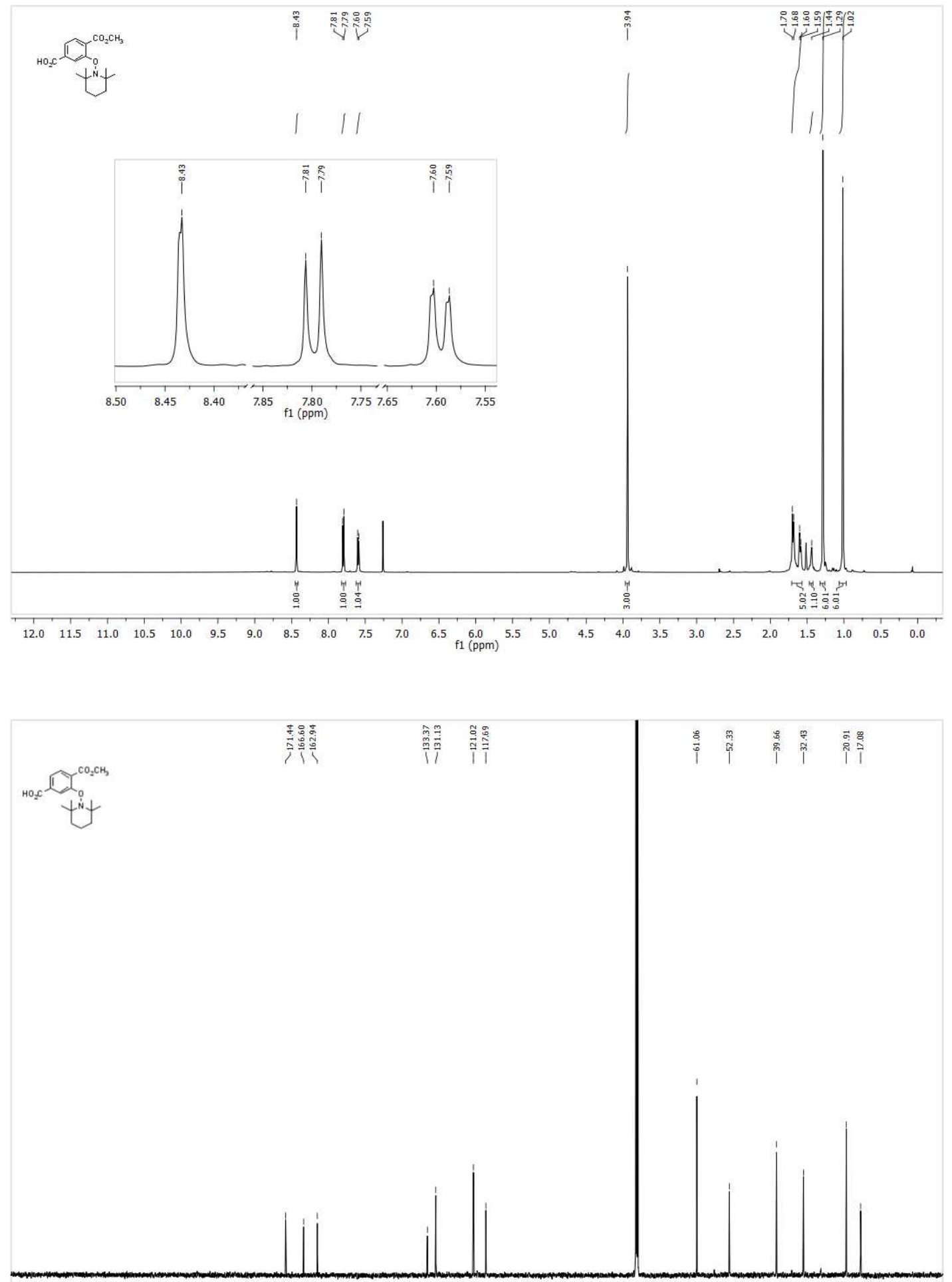

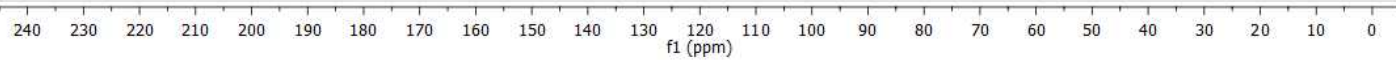



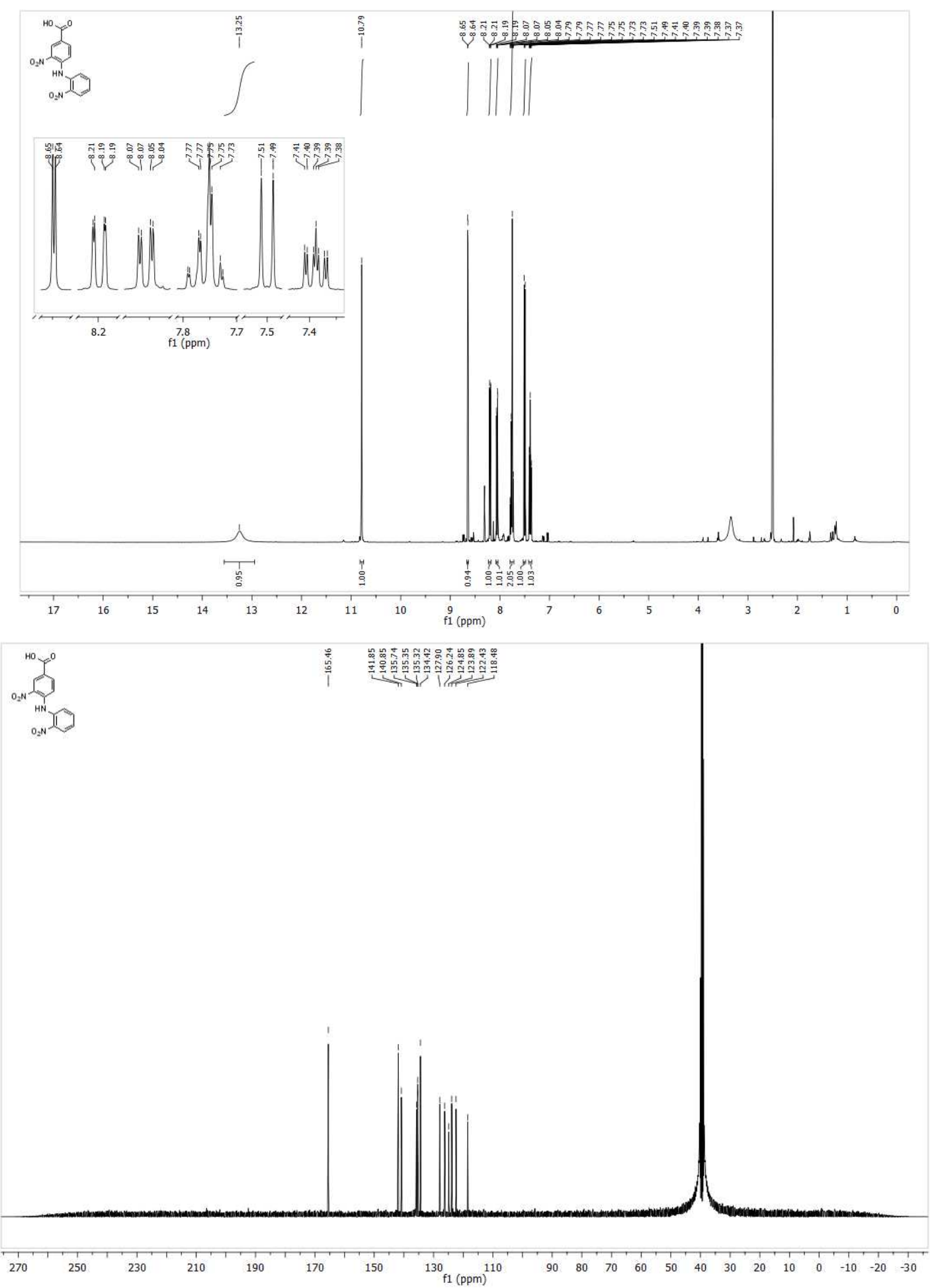


\section{REFERENCES}

1. Farkas, M.E., Rodriguez, E., Longo, C., Monasterios, M., Ortega, M.C., Rivas, A.B., Pardey, A.J., Lopez, R., and Moya, S.A. J. Chil. Chem. Soc., 2006, 51, 829.

2. Lakshminarayana, N., Prasad, Y.R., Gharat, L., Thomas, A., Narayanan, S., Raghuram, A., Srinivasan, C.V., and Gopalan, B. Eur. J. Med. Chem., 2010, 45, 3709.

3. De Leon-Rodriguez, L.M., Kovacs, Z., and Sherry, A.D. Lett. Org. Chem., 2005, 2, 160.

4. Rudzki, M., Alcalde-Aragones, A., Dzik, W.I., Rodriguez, N., and Goossen, L.J. Synthesis, 2012, 2012, 184.

5. Berger, S. and Diehl, B.W.K. Tetrahedron Lett., 1987, 28, 1243.

6. Threadgill, M.D. and Gledhill, A.P. J. Chem. Soc. , Perkin Trans. 1, 1986, 873.

7. Majek, M., Filace, F., and Jacobi von Wangelin, A. Chemistry - A European Journal, 2015, 21, 4518. 